\title{
REVIEW
}

\section{Overcoming oncogene addiction in breast and prostate cancers: a comparative mechanistic overview}

\author{
Eliot B Blatt ${ }^{1}$, Noa Kopplin'1, Shourya Kumar1, Ping Mu², Suzanne D Conzen³ and Ganesh V Raj1,4 \\ 1Department of Urology, University of Texas Southwestern Medical Center, Dallas, Texas, USA \\ 2Department of Molecular Biology, University of Texas Southwestern Medical Center, Dallas, Texas, USA \\ 3Department of Internal Medicine, University of Texas Southwestern Medical Center, Dallas, Texas, USA \\ ${ }^{4}$ Department of Pharmacology, University of Texas Southwestern Medical Center, Dallas, Texas, USA
}

Correspondence should be addressed to G V Raj: Ganesh.Raj@UTSouthwestern.edu

\begin{abstract}
Prostate cancer (PCa) and breast cancer (BCa) are both hormone-dependent cancers that require the androgen receptor (AR) and estrogen receptor (ER, ESR1) for growth and proliferation, respectively. Endocrine therapies that target these nuclear receptors (NRs) provide significant clinical benefit for metastatic patients. However, these therapeutic strategies are seldom curative and therapy resistance is prevalent. Because the vast majority of therapy-resistant PCa and BCa remain dependent on the augmented activity of their primary NR driver, common mechanisms of resistance involve enhanced NR signaling through overexpression, mutation, or alternative splicing of the receptor, coregulator alterations, and increased intracrine hormonal synthesis. In addition, a significant subset of endocrine therapy-resistant tumors become independent of their primary NR and switch to alternative NR or transcriptional drivers. While these hormone-dependent cancers generally employ similar mechanisms of endocrine therapy resistance, distinct differences between the two tumor types have been observed. In this review, we compare and contrast the most frequent mechanisms of antiandrogen and antiestrogen resistance, and provide potential therapeutic strategies for targeting both advanced PCa and BCa.
\end{abstract}

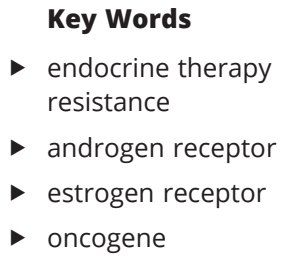

Endocrine-Related Cancer (2021) 28, R31-R46

\section{Introduction}

The vast majority of prostate cancers (PCa) and breast cancers (BCa) are hormone-dependent malignancies that grow when stimulated by androgens and estrogens, respectively. These hormones bind and activate their cognate nuclear receptors (NRs), androgen receptor (AR) and estrogen receptor (ER, ESR1), which then drive pro-proliferative transcriptional programs in cancer cells (Fig. 1). A number of antiandrogens targeting AR (enzalutamide, bicalutamide, flutamide, apalutamide, darolutamide) and antiestrogens targeting ER (tamoxifen, fulvestrant) have shown efficacy in and improved survival for patients. However, these drugs are rarely curative and endocrine therapy resistance is common, as cancer cells evolve mechanisms to maintain their dependence on their primary oncogenic drivers - their respective NRs. In this review, we will assess the similarities and differences in the mechanisms of endocrine therapy resistance to the representative antiandrogen, enzalutamide, and the canonical antiestrogen, tamoxifen, in PCa and BCa. Since the differences in the mechanisms 
Effect of NR agonists and antagonists in endocrine therapy-sensitive cancer
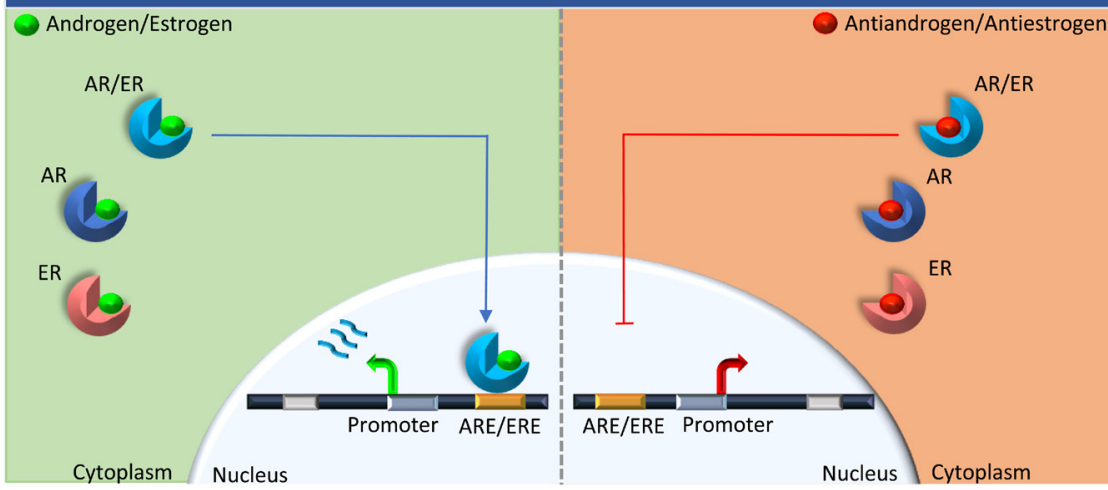

\section{Figure 1}

Effect of NR agonists and antagonists. Nuclear receptor (NR) agonists, such as androgens and estrogens, bind to the NR in the cytoplasm and cause translocation to the nucleus, where they bind their cognate NR-response elements on the DNA (ARE/ERE), and drive transcription of NR-regulated genes (green box). In contrast, NR antagonists bind to the NR, prevent nuclear translocation, DNA binding, and transcription of NR-regulated genes. As a consequence, NR antagonists shut down NR-driven gene expression (red box). A full color version of this figure is available at https://doi.org/10.1530/ERC-20-0272. of therapy resistance may be in part due to the antagonist used, we will first explore the salient features of both enzalutamide and tamoxifen.

\section{Enzalutamide}

Enzalutamide is a highly selective AR antagonist, possessing an increased (eight-fold) affinity for AR, compared to first-generation antiandrogens, including bicalutamide. However, enzalutamide still has a lower affinity (two-fold) for AR than the AR agonist dihydroxytestosterone (DHT) (Tran et al. 2009). Clinically, enzalutamide is approved for the treatment of non-metastatic and metastatic castrationresistant PCa (CRPC). In non-metastatic CRPC patients, enzalutamide delays the onset of metastasis by 36 months, while in newly diagnosed metastatic CRPC patients, it delays disease progression by 15 months (Hussain et al. 2018, Komura et al. 2019). Durable long-term responses to enzalutamide are rare, and disease progression is common.

\section{Tamoxifen}

Tamoxifen is a highly selective estrogen receptor modulator (SERM) with predominantly antagonistic properties in breast tissue. Tamoxifen binds to ER with equal or greater affinity than the ER agonist estradiol (E2) (Fabian et al. 1981, Katzenellenbogen et al. 1984). Clinically, tamoxifen is approved as an adjuvant treatment in primary breast cancer, and in this setting, increases overall and diseasefree survival by more than 96 months (Delozier et al. 2000). Tamoxifen is also used in the metastatic setting, primarily in premenopausal women. Since clinical intervention with tamoxifen usually occurs earlier in the progression of $\mathrm{BCa}$ than with enzalutamide in $\mathrm{PCa}$, the effects on survival are enhanced. However, as with enzalutamide-treated patients, disease recurrence remains prevalent and may occur after significant time ( $>10$ years) on tamoxifen therapy.

\section{Mechanisms of therapy resistance}

The majority of enzalutamide-resistant prostate cancer (EnzR-PCa) and tamoxifen-resistant breast cancer (TamR$\mathrm{BCa}$ ) maintain AR or ER signaling, respectively. To maintain an addiction to their cognate NR, most EnzR-PCa (70\%) and TamR-BCa (60\%) either amplify the expression of their oncogenic NR or modify the NR protein with alternative splicing, gene fusions, or point mutations to enable therapy resistance. In contrast, some EnzR-PCa (10-15\%) and TamR-BCa (15-30\%) are marked by a loss of NR expression (and consequently their NR addiction), and rely on alternative molecular drivers (Johnston et al. 1995, Robinson et al. 2015, Abida et al. 2019).

In this review, we will assess eight distinct potential mechanisms of antiandrogen and antiestrogen resistance based on four criteria: (1) enrichment of mechanistic drivers in therapy-resistant patient tumors, (2) the ability of the mechanistic drivers to independently mediate therapy resistance, (3) capability of pharmacological inhibition or genetic ablation of these drivers in restoring drug (enzalutamide or tamoxifen) sensitivity, and (4) the clinical utility of drugs targeting the mechanistic drivers in therapy-resistant patients.

\section{NR overexpression}

NR overexpression alters the stoichiometric ratio of the receptor to the antagonist (enzalutamide or tamoxifen), potentially overwhelming the antagonist's ability to effectively neutralize NR activity (Fig. 2). As a result, cancer cells display hypersensitivity to agonists even under treatment conditions (Chen et al. 2004, Tran et al.
(C) 2021 Society for Endocrinology Published by Bioscientifica Ltd. Printed in Great Britain 


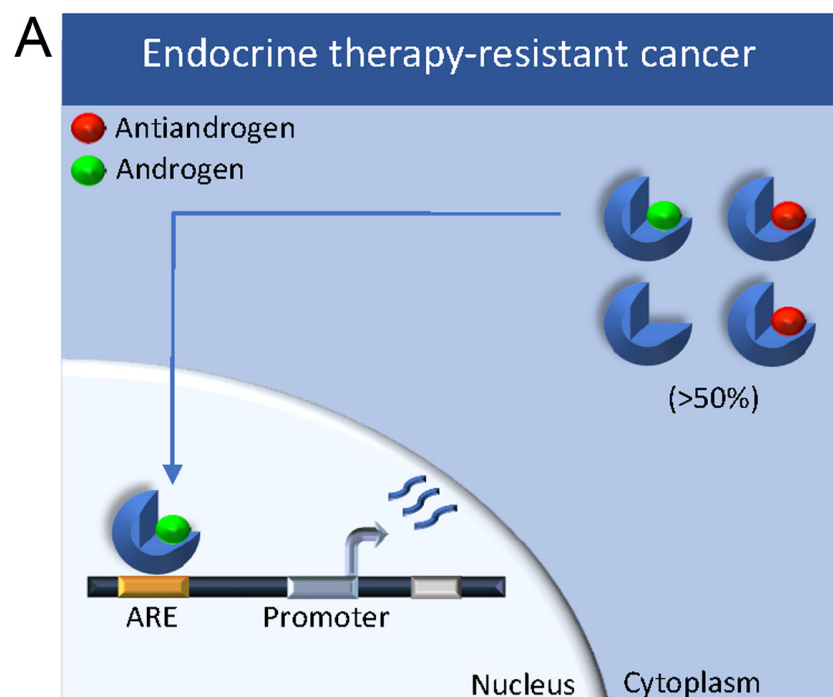

B

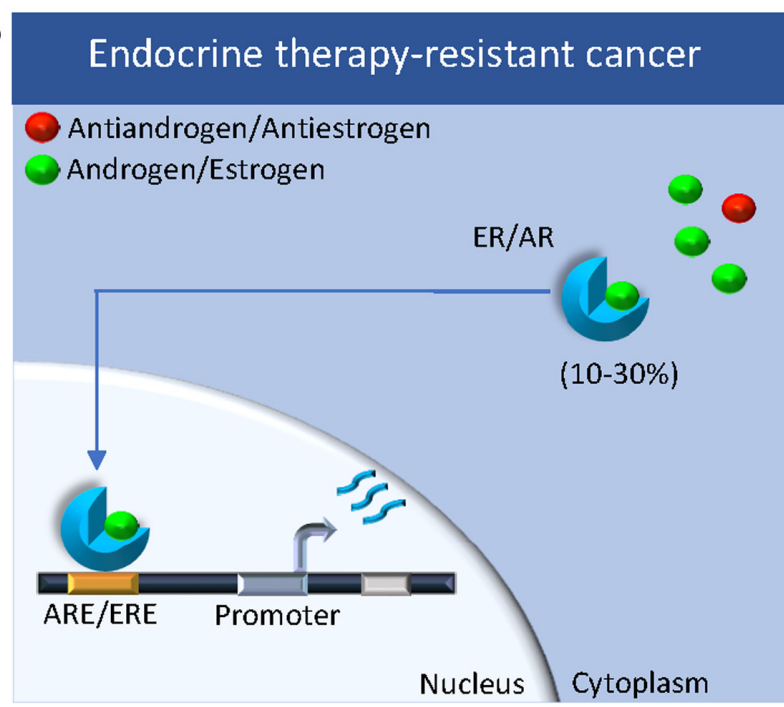

Figure 2

NR activation in endocrine therapy-resistant cancers. (A) NR overexpression (shown for AR): AR overexpression alters the stoichiometric ratio of AR to antagonist, enabling availability of AR to bind to even small amounts of agonists and activate gene expression. NR overexpression is not as commonly seen with ER after tamoxifen therapy. (B) Enhanced NR ligand synthesis: enhanced ligand synthesis can increase the stoichiometric ratio of agonist to antagonists, effectively outcompeting antagonists to bind NR, and increase activation of NR transcriptional programs. This mechanism of resistance has been reported for both AR and ER. Percentages within parentheses after each mechanism reflect their known prevalence. A full color version of this figure is available at https://doi.org/10.1530/ERC-20-0272.

2009, Kawata et al. 2010). This mechanism of resistance is more commonly observed in EnzR-PCa than TamR-BCa.

\section{NR overexpression in PCa}

A majority (>70\%) of EnzR-CRPC patients have AR pathway alterations, resulting in enhanced AR signaling.
Increased AR expression is driven either by genomic amplification of AR or the more recently discovered enhancer amplification. Observed in up to $50 \%$ of cases, AR gene amplification is one of the most frequent genetic alterations reported for CRPC tumors (Grasso et al. 2012, Robinson et al. 2015, Abida et al. 2019). In contrast to primary tumors, AR amplification is commonly seen in EnzR-CRPC, and is predictive of poorer outcomes (Azad et al. 2015). More recent reports show amplification of an enhancer locus $\sim 650 \mathrm{~kb}$ upstream of the AR gene in CRPC tumors, but not localized tumors. This enhancer is enriched for H3K27 acetylation, and chromosome capture analysis indicates that this putative enhancer region interacts with the AR promoters, directly contributing to the transcriptional upregulation of the AR gene (Takeda et al. 2018, Ramanand et al. 2020). Ultimately, the authors showed that the AR gene enhancer was required for EnzRCRPC cell survival, as AR enhancer knock-in sufficiently conferred enzalutamide resistance to enzalutamidesensitive cells. This study and confirmatory studies demonstrated the clinical relevance of this AR enhancer, where almost $90 \%$ of metastatic CRPC (mCRPC) tumors (compared to $<1 \%$ of primary tumors) and $70 \%$ of mCRPC patients by cell-free DNA analysis contained this duplication (Viswanathan et al. 2018, Ramanand et al. 2020). Taken together, these endocrine therapyinduced alterations dramatically enhance AR expression in EnzR-CRPC. Thus, developing therapeutic strategies with more potent antiandrogen or degrading activity may be an effective means to overcome enzalutamide resistance driven by AR overexpression. Clinical trials with AR-targeted degraders, such as ARV-110, have already begun to show promising results (NCT03888612).

\section{NR overexpression in $\mathrm{BCa}$}

Similarly, ER is the driver in ER+ BCa, which accounts for $70 \%$ of breast cancers. While the majority of TamR-BCa still express some ER, loss of ER is a primary mechanism of endocrine therapy resistance in patients, whereas overexpression of ER is much less common (Encarnación et al. 1993, Dowsett \& Haynes 2003). ER copy-number alterations (gain or amplification) are noted in $15 \%$ of metastatic and just $5 \%$ of primary $\mathrm{ER}+\mathrm{BCa}$; however, no definitive correlation exists between ER amplification and survival outcomes, as some data suggest that ER amplification may be associated with improved clinical response to antiestrogens (Holst et al. 2007, Tomita et al. 2009, Basudan et al. 2019). Unlike AR amplification in PCa, further investigation is required to determine whether ER 
amplification can be considered a proven mechanism of antiestrogen resistance. As a result, therapeutic strategies specifically designed to overcome ER overexpression have not yet been explored.

\section{Point mutations in the NR ligand-binding domain}

Since antagonists target the NR ligand-binding domain (LBD), point mutations in the NR LBD can effectively inhibit antagonist activity. Moreover, these point
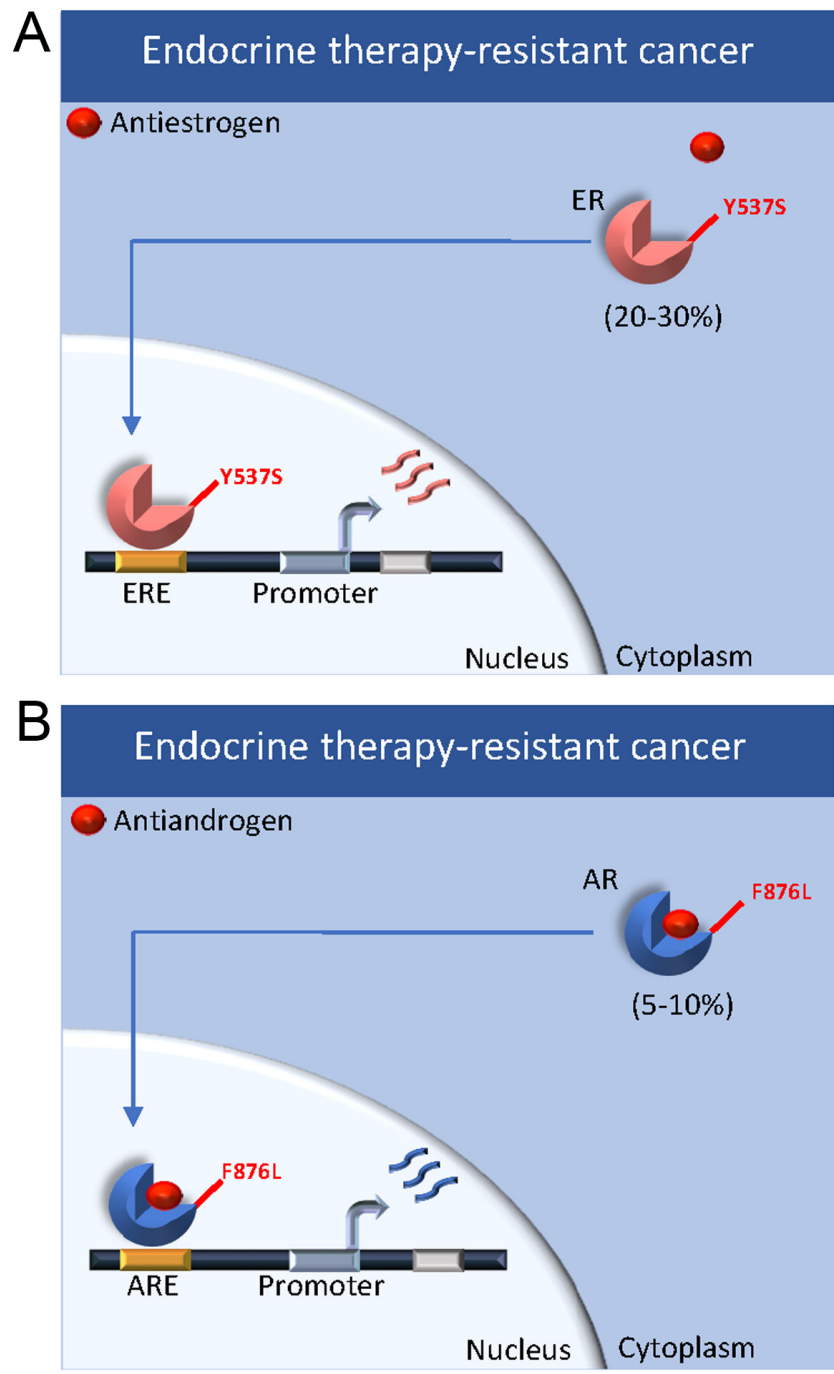

Figure 3

Point mutations in the NR ligand-binding domain (LBD). (A) ER proteins with LBD point mutations, such as the Y537S, are constitutively nuclear, do not bind antiestrogens, and are capable of activating transcription from an ERE in a ligand-independent manner. (B) In contrast, AR proteins with LBD point mutations, such as the F876L, convert their antagonists into agonists and drive transcription from an ARE. Percentages within parentheses after each mechanism reflect their known prevalence. A full color version of this figure is available at https://doi.org/10.1530/ERC-20-0272. mutations may convert the antagonist to an agonist or represent a gain-of-function (GOF) mutation and contribute to endocrine therapy resistance due to constitutive activation of the receptor (Fig. 3).

\section{Point mutations in the AR LBD in PCa}

The selective pressure of each antiandrogen is associated with specific point mutations in the AR LBD, as evidenced by the AR T877A mutation for flutamide, AR W741C mutation for bicalutamide, and AR F876L for enzalutamide and apalutamide. These point mutations convert the antagonist to an agonist, and independently drive resistance to specific antiandrogens (Veldscholte et al. 1990, Hara et al. 2003, Chen et al. 2004, Balbas et al. 2013, Joseph et al. 2013) (Fig. 3). Consequently, another antiandrogen may still have activity against the AR LBD point mutants. For example, AR T877A and W741C mutants are sensitive to enzalutamide and apalutamide (Chen et al. 2004). Although these mutations to the AR LBD have been identified in patient tumor samples and are recognized as drivers of antiandrogen resistance, their individual observed frequencies are low. As AR mutants develop in response to specific antiandrogens, more potent antiandrogens or AR degraders may also be effective against AR mutants.

\section{Point mutations in the ER LBD in BCa}

ER LBD mutations are seen in $\sim 20-30 \%$ of endocrine therapy-resistant BCa (Toy et al. 2013, Razavi et al. 2018). The most common ER LBD mutants are Y537S, Y537N, and D538G. These mutations induce a significant conformational change in the ER LBD that even in the absence of estrogens, effectively lock the ER LBD into a constitutively active state (Zhang et al. 1997, Nettles et al. 2008, Toy et al. 2017) (Fig. 3). For example, the Y537S mutation stabilizes helix 12 in a conformation that allows a coactivator to bind in an estrogen-independent manner by forming a hydrogen bond with another amino acid in the LBD (Nettles et al. 2008). Consequently, these ER LBD mutants are always functionally active, are insensitive to tamoxifen, and can drive TamR-BCa in vitro (Toy et al. 2017, Fanning et al. 2018) (Fig. 3). Importantly, E2 can bind to these ER LBD mutants, enhance interaction with coregulators, and further increase transcriptional activity driven by these mutants (Toy et al. 2017, Fanning et al. 2018). BCa cells with ER LBD mutations are still driven by ER, and thus retain some sensitivity to selective ER degraders, such as fulvestrant. Multiple preclinical compounds that are effective in the ER mutant setting, 
including bazedoxifene and ERX-11, are in development, yet their clinical efficacy in therapy-resistant tumors awaits confirmation (Raj et al. 2017, Fanning et al. 2018, Viswanadhapalli et al. 2019).

\section{NR splice variants}

The expression of alternatively spliced isoforms of NRs that naturally occur in low frequencies can be enhanced following selection pressure by endocrine therapies. These isoforms can drive the NR transcriptional program in a ligand-independent manner, albeit less effectively than in the ligand-dependent mechanism (Fig. 4).

\section{NR splice variants in PCa}

AR-variants (AR-Vs), such as AR-V7 and AR-V9, have been widely detected in CRPC, and their expression is further increased in patients treated with antiandrogens, such as enzalutamide (Guo et al. 2009, Hörnberg et al. 2011, Antonarakis et al. 2014, Kohli et al. 2017, Luo et al. 2018, Li et al. 2020). These AR-Vs typically lack the LBD and remain constitutively active in the absence of androgens (Dehm et al. 2008, Guo et al. 2009, Li et al. 2013b, Kohli et al. 2017, Luo et al. 2018) (Fig. 4). In addition, induction of AR-V expression in antiandrogen-sensitive PCa cells promotes resistance to both bicalutamide and enzalutamide ( $\mathrm{Li}$ et al. 2013b). Expression of AR-V7 in metastatic tumors correlates with poor clinical response to AR-targeted therapies, and the loss of AR-V7 in antiandrogen-resistant cells has been shown to restore antiandrogen sensitivity in vitro (Li et al. 2013b, 2020, Antonarakis et al. 2014). While AR-Vs are transcriptionally active and can drive resistance, their increased expression is typically concordant with AR amplification, and their role as an independent molecular driver of resistance remains undetermined (Watson et al. 2010, Hörnberg et al. 2011, Li et al. 2013b, 2020, Luo et al. 2018). Only with the emergence of effective AR-V-targeted therapies, can the role of AR-Vs in EnzRPCa be clarified. Trials with niclosamide are ongoing (NCT02532114, NCT03123978). Thus, while high AR-V expression is a viable biomarker of insensitivity to AR-targeted therapies, they have not yet been proven as a direct molecular driver of therapy resistance or as a viable therapeutic target.

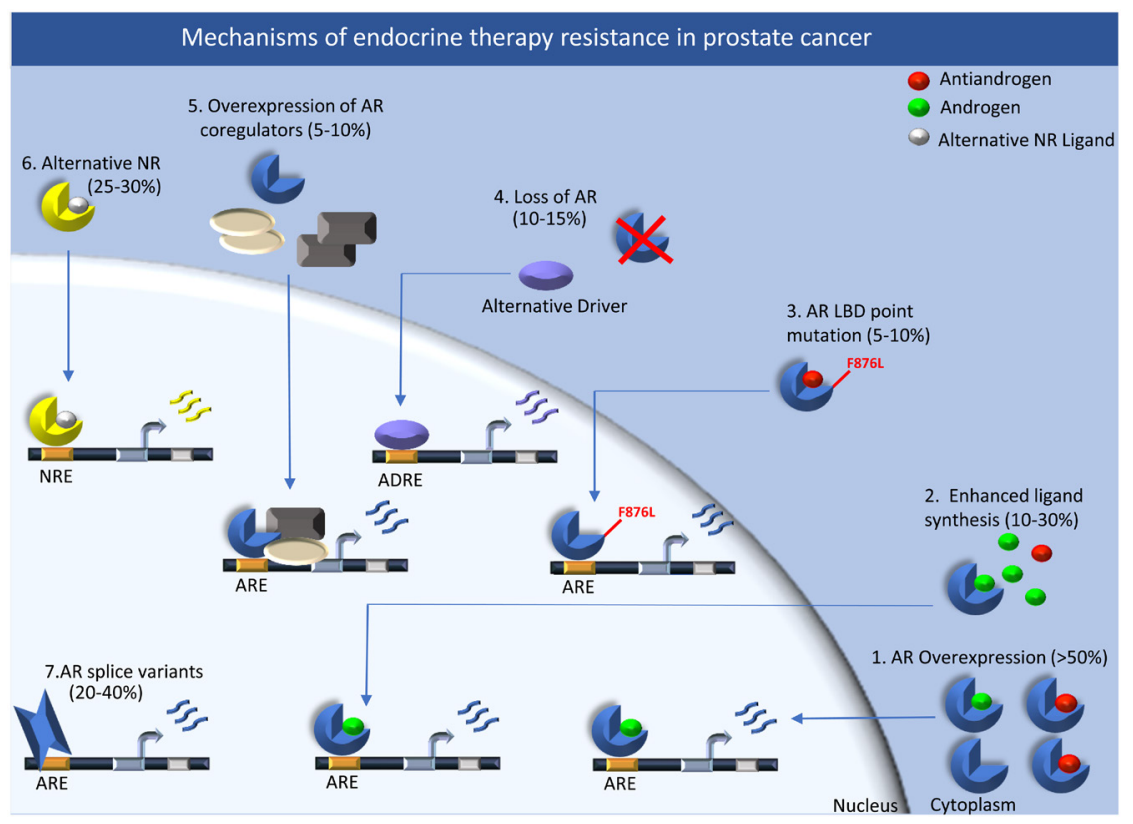

Figure 4

Comparative overview of the most common mechanisms driving endocrine therapy resistance in prostate cancers. 1. AR overexpression alters the stoichiometric ratio of AR to antagonist, enabling AR to bind to even small amounts of agonists and activate gene expression. 2. Enhanced ligand synthesis can increase the stoichiometric ratio of agonist to antagonists, effectively outcompeting antagonists to bind $A R$, and increase activation of AR transcriptional programs. 3. AR proteins with LBD point mutations, such as the F876L, convert their antagonists into agonists and drive transcription from an ARE. 4. Under the selection pressure of endocrine therapy, AR loss can occur. Alternative non-AR drivers can induce AR-independent transcriptomes to drive the progression from an alternative driver response element (ADRE). 5. Overexpression of AR coregulators effectively increase AR-mediated transcription in the presence of antagonists. 6 . Alternative NR drivers may overcome antagonistic blockade of the AR and activate an alternative NR-driven transcriptional program. 7. AR-variants (AR-Vs) form homodimers or heterodimers with full-length AR (AR-FL), are constitutively nuclear, can bind DNA either as a homodimer or heterodimer, and activate AR transcriptional programs. AR-Vs lack the AR-LBD, and are thus not responsive to antagonists. Percentages within parentheses after each mechanism reflect their known prevalence. A full color version of this figure is available at https://doi.org/10.1530/ERC-20-0272.

https://erc.bioscientifica com https://doi.org/10.1530/ERC-20-0272 (c) 2021 Society for Endocrinology Published by Bioscientifica Ltd. Printed in Great Britain 


\section{NR splice variants in $\mathrm{BCa}$}

ER splice variants have been detected in TamR-BCa. However, their role as a molecular driver in promoting endocrine therapy resistance is unclear and requires further investigation (Beije et al. 2018).

\section{Enhanced NR ligand synthesis}

Enhanced synthesis of androgens and estrogens within the tumor microenvironment can effectively alter the stoichiometric ratio of the NR, agonist, and antagonist to overcome the ability of the antagonist to effectively inhibit NR activity (Fig. 3).

\section{Enhanced ligand synthesis in PCa}

Intratumoral androgen synthesis is increased in CRPC and overcomes the pituitary suppression of androgen synthesis by the testes. Abiraterone is a secondgeneration androgen synthesis inhibitor that blocks adrenal and intratumoral androgen synthesis, providing significant clinical benefit to CRPC patients (Locke et al. 2008, Cai et al. 2011, Mohler et al. 2011, Mostaghel et al. 2011, Fankhauser et al. 2014, Liu et al. 2015, 2019). In EnzR cells, upregulation of aldo-keto reductase family 1 member C3 (AKR1C3) has been shown to enhance intracrine androgen synthesis and subsequently enzalutamide resistance. Loss of AKR1C3 by genetic ablation or pharmacological inhibition causes EnzR-PCa cells to become enzalutamide-sensitive in vitro and in vivo (Liu et al. 2015, 2019). Clinical trials in CRPC patients with a combination of enzalutamide and AKR1C3 inhibitors (NCT02935205) are ongoing but are likely to have limited utility, since increased AKR1C3 expression has only been shown in a small percentage of EnzR-PCa patients. Cholesterol is required for steroid synthesis. In PCa, overexpression of 3-hydroxy-2-methyl-glutarylCoA reductase (HMGCR), the rate-limiting enzyme for cholesterol synthesis, may mediate enzalutamide resistance (Brown \& Goldstein 1980, Kong et al. 2018). Additionally, cholesterol synthesis inhibitors suppress the growth of EnzR-PCa in vitro and in vivo (Kong et al. 2018). The clinical utility of this remains to be seen.

\section{Enhanced ligand synthesis in $\mathrm{BCa}$}

The most compelling evidence for increased hormone synthesis driving antiestrogen resistance comes from the clinic, where aromatase inhibitors (AI) have repeatedly shown to increase overall survival and duration of response in metastatic TamR-BCa patients (Dombernowsky et al.
1998). Aromatase is a cytochrome $\mathrm{P} 450$ that promotes ER activation by converting androgens into estrogens (Brodie 1985). Mechanistic studies have further shown that TamR-BCa cells have increased aromatase expression and activity, aromatase precursors increase the growth of TamR cells, and TamR cell growth is inhibited by aromatase inhibitors in vitro (Catalano et al. 2014). Like in PCa, cholesterol synthesis may play an important role in antiestrogen resistance. Studies have indicated that supplementation with cholesterol precursors promotes tamoxifen resistance, and cholesterol synthesis inhibitors suppress the growth of TamR-BCa in vivo (Nelson et al. 2013). However, similar to PCa, the clinical relevance of this remains unclear.

\section{NR coregulators and transcriptional machinery}

NR coregulators (coactivators and corepressors) are essential for modulating NR-mediated transcription at either the promoter or chromatin level (Figs 4 and 5). Coactivators typically bind the NR when it is bound by the agonist, increasing gene transcription, while corepressors are recruited when the antagonist is bound, decreasing target gene expression (Halachmi et al. 1994, Baniahmad et al. 1995, Cavaillès et al. 1995, Chen \& Evans 1995, Oñate et al. 1995). A number of NR coregulators are overexpressed in hormone-dependent malignancies and can enhance NR activity. The high expression of some coactivators may enhance NR agonist activity and contribute to endocrine therapy resistance (Figs 4 and 5). Conversely, lower levels of corepressors may reverse the drug's role from antagonist to agonist, ultimately driving therapy resistance.

\section{NR coregulators and transcriptional machinery in PCa}

AR coactivators, such as nuclear receptor coactivator 2 (NCOA-2, SRC-2, TIF-2), are upregulated in MCRPC and correlate with worse recurrent-free survival (Agoulnik et al. 2006, Robinson et al. 2015, Abida et al. 2019). Genetic ablation of SRC-2 restores bicalutamide sensitivity in PCa cells (Feng et al. 2009). Additionally, knockdown of pioneering factors, such as forkhead box A1 (FOXA1), which are altered in a small subset (10\%) of mCRPC patients, overcomes resistance to enzalutamide (Jin et al. 2014, Abida et al. 2019, Hwang et al. 2019). Other coregulators that may be important for antiandrogen resistance and require further investigation include nuclear receptor coactivator 3 (SRC-3) and E1A binding protein p300 (p300/СBP300), 


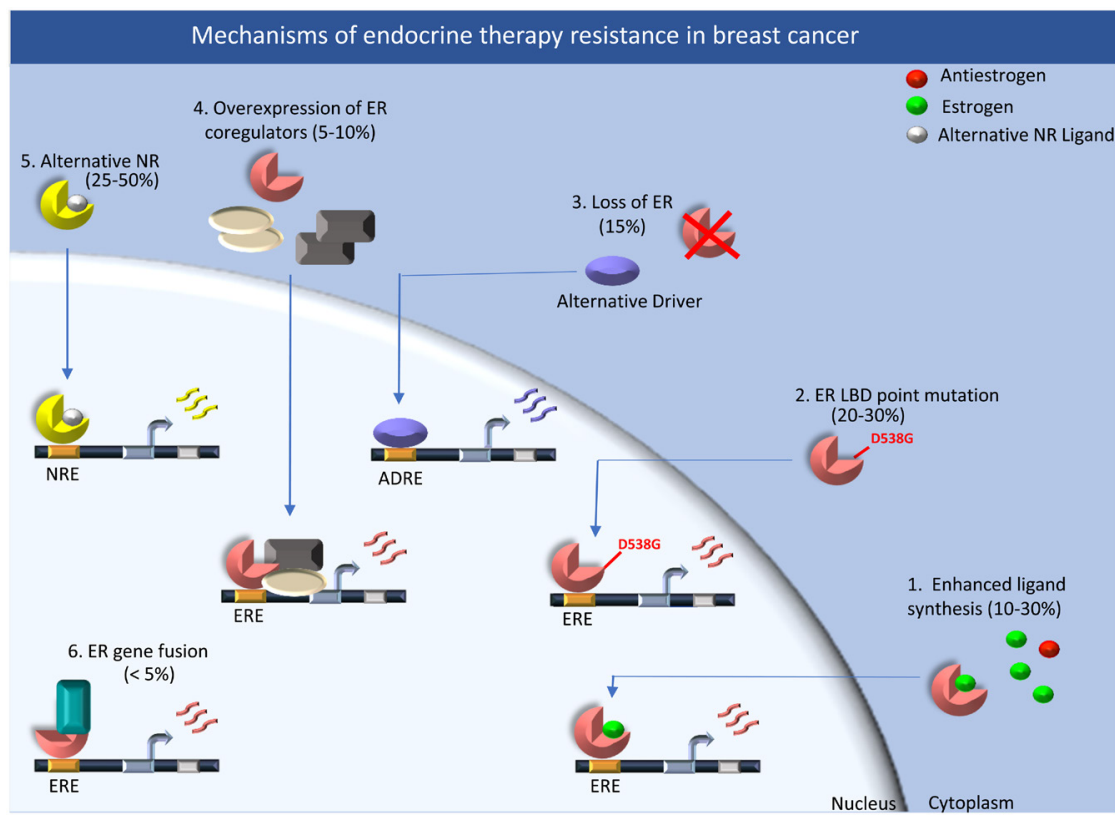

\section{Figure 5}

Comparative overview of the most common mechanisms driving endocrine therapy resistance in breast cancers. 1. Enhanced ligand synthesis can increase the stoichiometric ratio of agonist to antagonists, effectively outcompeting antagonists to bind $E R$, and increase activation of ER transcriptional programs. 2. ER proteins with LBD point mutations, such as the Y537S, are constitutively nuclear, do not bind antiestrogens, and are capable of activating transcription from an ERE in a ligand-independent manner. 3. Under the selection pressure of endocrine therapy, ER loss can occur. Alternative non-NR drivers can drive NR-independent transcriptomes from alternative driver response elements (ADRE) to drive progression. 4. Overexpression of ER coregulators effectively increase ER-mediated transcription in the presence of antagonists. 5 . Alternative NR drivers may overcome antagonistic blockade of the ER and activate an alternative NR-driven transcriptional programs. 6. Gene fusions between the ER $\mathrm{N}$-terminus and other genes create hybrid proteins that have the ER $\mathrm{N}$-terminus and a different protein in place of the ER LBD. Consequently, these ER fusion proteins are no longer responsive to either ER agonists or antagonists. Instead, these fusion proteins are able to bind the ERE and activate ER-driven transcriptional programs. Percentages within parentheses after each mechanism reflect their known prevalence. A full color version of this figure is available at https://doi.org/10.1530/ ERC-20-0272.

which are associated with worse progression-free survival (PFS) (Debes et al. 2003, Zhou et al. 2005, Abida et al. 2019). Conversely, deletion or loss-of-function (LOF) mutations of either nuclear receptor corepressor 1 or 2 (NCOR1 or NCOR2) are seen in $5-10 \%$ of mCRPC patients, and have been shown to promote resistance to enzalutamide in PCa cells in vitro (Robinson et al. 2015, Lopez et al. 2016, Abida et al. 2019). Additionally, genetic ablation of NCOR1 has been shown to promote bicalutamide and enzalutamide resistance in sensitive cells in vitro (Lopez et al. 2016). While these data are suggestive, clear mechanistic evidence for the ability of coregulators to independently drive antiandrogen resistance in vivo is lacking.

\section{NR coregulators and transcriptional machinery in BCa}

Amplification of multiple ER coregulators has been reported in TamR-BCa. Overexpression of one such ER coactivator, SRC-3, has been shown to increase the agonist activity of tamoxifen in vitro and contributes to tamoxifen resistance (Anzick et al. 1997, Weiner et al. 2013). Small-molecule compounds inhibiting SRC-3 in both in vitro and in vivo models have been shown to re-sensitize resistant cells to tamoxifen (Wang et al. 2014, Song et al. 2016). Similar to EnzR-PCa, the pioneering factor FOXA1 is overexpressed in TamR cells and xenografts and drives TamR-BCa in vitro, as evidenced by the ability of FOXA1 knockdown to restore tamoxifen sensitivity (Fu et al. 2016). As in EnzR-PCa, loss of NCOR expression may play a role in tamoxifen resistance. Low NCOR expression correlates with worse relapse-free survival, and NCOR is decreased in TamR-BCa (Girault et al. 2003, Lu et al. 2016). In vitro and in vivo studies have shown that inhibiting NCOR with an NCOR-blocking antibody leads to tamoxifen resistance by conferring tamoxifen with agonistic properties (Lavinsky et al. 1998). Compounds targeting coregulators including SRC-3 inhibitors, such as SI-2, bufalin, and gossypol, are in development (Wang et al. 2014, Song et al. 2016).

\section{NR gene fusions}

Intragenic gene fusions with NRs can create novel NR fusion products that no longer respond to either agonists or antagonists, and thus promote therapy resistance (Fig. 5). (c) 2021 Society for Endocrinology Published by Bioscientifica Ltd. Printed in Great Britain 
Table 1 Common mechanisms of antiandrogen and antiestrogen resistance in prostate and breast cancer.

\begin{tabular}{l} 
Mechanism \\
\hline NR overexpression \\
Point mutations in the NR \\
LBD \\
NR splice variants \\
Enhanced NR ligand \\
synthesis \\
NR coregulators and \\
transrptional machinery
\end{tabular}

NR gene fusions

Alternative NR drivers

Alternative non-NR drivers

\begin{tabular}{l} 
Antiestrogen resistance \\
\hline Rare $(<5 \%)$ \\
Not proven driver of resistance
\end{tabular}

Y537S, Y537N, and D538G are well-described (20-30\%)

Known driver of resistance

Rare $(<5 \%)$

Not proven driver of resistance

Well-described (10-30\%)

Proven mechanism of resistance

NCOR, SRC family, and FOXA1 alterations are infrequent (5-10\%)

Not proven driver of resistance

Rare $(<5 \%)$

Not proven driver of resistance

ER- $\beta$, ERR $\alpha$, PR alterations seen (25-30\%)

Not proven driver of resistance Enhanced MAPK and Cyclin

D-CDK4/6 signaling well-

described (15\%)

Known driver of resistance

\begin{tabular}{l} 
Therapeutic strategy \\
\hline PCa: More potent AR antagonists \\
or degraders (ARV-110) \\
BCa: Not yet explored \\
PCa: More potent AR antagonists \\
BCa: SERMs or SERDs \\
(bazedoxifene, ERX-11) \\
PCa: Niclosamide \\
BCa: N/A \\
PCa: Abiraterone, AKR1C3 \\
inhibitors \\
BCa: Aromatase inhibitors (AI) \\
PCa: SRC-3 inhibitors \\
BCa: SRC-3 inhibitors \\
N/A \\
PCa: GR antagonists \\
BCa: ERR $\alpha$ antagonists or PR \\
modulators + antiestrogens \\
PCa: SOX2/BRN2/ATM inhibitors \\
BCa: EGFR and ERK/MEK \\
inhibitors, CDK4/6 inhibitors \\
(palbociclib) + Al
\end{tabular}

Table displaying eight mechanisms of therapy resistance in prostate and breast cancer, their relative frequencies, and potential therapeutic strategies currently under investigation.

AKR1C3, aldo-keto reductase family 1 member C3; AR, androgen receptor; ATM, ataxia telangiectasia mutated; BRN2, POU-domain transcription factor BRN2; CDK, cyclin-dependent kinase; EGFR, EGF receptor; ERK, extracellular signal-regulated kinase; ERR $\alpha$, estrogen-related receptor $\alpha$; ER- $\beta$, estrogen receptor- $\beta$; forkhead box A1; FOXA1; GR, glucocorticoid receptor; LBD, ligand-binding domain; MAPK, mitogen-activated protein kinase; MEK, MAPK/ERK kinase (MEK) ; NCOR, nuclear receptor corepressor; PR, progesterone receptor; RB1, retinoblastoma 1; SERDs, selective estrogen receptor degraders; SERMs, selective estrogen receptor modulators; SOX2, SRY-box 2; SRC, nuclear receptor coactivator; TP53, tumor protein p53.

\section{NR gene fusions in $\mathrm{PCa}$}

NR gene fusions have primarily been reported in $\mathrm{BCa}$, not in $\mathrm{PCa}$, and have no known role in antiandrogen resistance (Table 1).

\section{NR gene fusions in $\mathrm{BCa}$}

Transcriptomic analysis of $\mathrm{ER}+\mathrm{BCa}$ has identified an enrichment in ER C-terminal fused proteins: ESR1e6>YAP1 (ESR1-YAP1) and ESR1-e6>PCH11X (ESR1PCDH11X) in late-stage, therapy-resistant BCa (Lei et al. 2018). These rearrangements result in an ER fusion protein that lacks the LBD, but can drive estrogen-independent growth, constituently activate ER transcriptional programs, and remain resistant to ER degraders, like fulvestrant (Lei et al. 2018) (Fig. 5). These fusions are difficult to therapeutically target but fortunately have only been identified in a small subset of patients with endocrine therapy-resistant BCa (Li et al. 2013a, Hartmaier et al. 2018, Lei et al. 2018). Further efforts are needed to prove whether ER gene fusions are a definitive mechanism of endocrine resistance.

\section{Alternative NR drivers}

Overlap in the NR ligand affinities, NR-DNA binding elements, and NR transcriptional programs contributes to significant redundancy, NR cross-talk, and NR substitution in hormone-dependent cancers. Thus, activation of other NRs can effectively overcome antagonistic blockade of the oncogenic NR (Figs 4 and 5).

\section{Alternative NR drivers in PCa}

Of the NR3C family members, NR3C1, otherwise known as the glucocorticoid receptor (GR), can effectively substitute for NR3C4 (AR). Upregulation of GR expression is noted in EnzR-PCa cells, xenografts, and patient tumors (Arora et al. 2013, Puhr et al. 2018, Zhang et al. 2020). More than $50 \%$ of AR DNA binding sites can also be bound by GR (Arora et al. 2013). Additionally, GR agonists can induce enzalutamide resistance in enzalutamide-sensitive cells in vitro. Conversely, GR knockdown by RNAi or GR antagonists cause EnzRPCa cells to regain sensitivity in vitro and in vivo (Arora et al. 2013, Puhr et al. 2018). Since GR activation can 
effectively substitute for AR as a molecular driver in PCa, GR antagonists are being evaluated in ongoing clinical trials (NCT03437941).

\section{Alternative NR drivers in $\mathrm{BCa}$}

The closely related NR3B family member, NR3B2 (ER- $\beta)$, is highly homologous to NR3B1 (ER- $\alpha$ ) in its DNA-binding domain and its LBD, and binds estradiol with similar affinity to ER- $\alpha$ (Brzozowski et al. 1997, Shiau et al. 2002). Initial reports indicated that the median ER- $\beta$ mRNA levels were two-fold higher than ER- $\alpha$ levels in TamR$\mathrm{BCa}$, compared with tamoxifen-sensitive tumors (Speirs et al. 1999). However, decreased expression of ER- $\beta$ protein was observed in higher grade $\mathrm{BCa}$, suggesting a protective role for ER- $\beta$ against the mitogenic effects of estrogen in advanced cancers (Roger et al. 2001). Three additional NRs may modulate ER activity in BCa - the estrogen-related receptor alpha (ERR $\alpha)$, the progesterone receptor (PR), and AR. Increased ERR $\alpha$ expression has been noted in TamR patient tumors and correlates with overall survival on tamoxifen. Furthermore, genetic ablation of ERR $\alpha$ inhibits TamR cell proliferation in vitro (Thewes et al. 2015). The role of PR in endocrine therapy resistance is controversial. PR expression has been shown to be beneficial: ER+/PR$\mathrm{BCa}$ is more resistant to tamoxifen than $\mathrm{ER}+/ \mathrm{PR}+$ tumors, and PR loss is associated with progression (Bardou et al. 2003). Mechanistic studies indicate that in the presence of agonists, PR associates with ER- $\alpha$ to direct ER- $\alpha$ chromatin binding events in $\mathrm{BCa}$ cells, resulting in a unique gene expression program associated with positive clinical outcomes (Mohammed et al. 2015). While the cooperative effects of ER and PR argue that PR antagonists, rather than agonists, should be used for treating advanced BCa (Singhal et al. 2016), other studies indicate that $\mathrm{PR}$, independent of ligand, enhances the expression of proliferative and invasive estrogen-induced target genes (Daniel et al. 2015). Much like PR, the role of AR in both $\mathrm{ER}+$ and ER- BCa is controversial. TamR-BCa have higher $\mathrm{AR}$ expression and a higher AR:ER ratio, which correlates with a poorer prognosis (Cao et al. 2019). Mechanistically, AR may enable maximal ER chromatin binding, with AR redirected to ER-bound promoter elements in an estrogendependent manner (D'Amato et al. 2016). Some studies show that AR antagonists inhibit the growth of TamRBCa in vitro and in vivo (D'Amato et al. 2016, Creevey et al. 2019). However, other studies have indicated that AR+ $\mathrm{BCa}$ patients may have a better prognosis, and that AR agonists inhibit the growth of $\mathrm{ER}+\mathrm{BCa}$, including those driven by mutant ER (Witzel et al. 2013, Aleskandarany et al. 2016, Ponnusamy et al. 2019). The luminal subtype of triple-negative breast cancer (TNBC) characterized by AR expression may be associated with a better prognosis $(\mathrm{Hu}$ et al. 2017), but the role of $\mathrm{AR}$ as the primary molecular driver in this subset remains to be proven. The utility of AR-targeted agents (like enzalutamide) in this subset of TNBC is being evaluated in clinical trials. Although ERR $\alpha$ antagonists may provide some clinical benefit for TamR$\mathrm{BCa}$ patients, the role $\mathrm{PR}$ and AR play in therapy resistance requires further study.

\section{Alternative non-NR drivers}

In order to adapt to the selection pressure of NR-targeted therapies, hormone-dependent cancers sometimes lose their dependence on their primary oncogenic NR. Since a significant proportion ( $>5 \%$ ) of the entire transcriptional program within these hormone-dependent cancers is driven by the NR, drastic changes within the cancer cell are required (Holzbeierlein et al. 2004, Sharma et al. 2013). Some hormone-dependent cancers dynamically decrease their NR expression in response to selection pressure and evade the effect of the targeting agent. In others, NR expression level may not be changed, but the canonical NR signaling program is lost (Figs 4 and 5).

\section{Alternative drivers in $\mathrm{PCa}$}

A small subset of EnzR-PCa (10-15\%) lose AR signaling and undergo lineage plasticity, characterized by epigenetic reprogramming and the acquisition of neuroendocrine characteristics, which allows previously AR-dependent cells to become AR independent (Robinson et al. 2015, Abida et al. 2019). Concomitant loss of tumor protein p53 (TP53) and retinoblastoma 1 (RB1) mediate this programmatic shift. Loss of TP53 and RB1 in enzalutamidesensitive cells has been shown to promote resistance in vitro and in vivo through a number of downstream mediators, including SRY-box 2 (SOX2), POU-domain transcription factor BRN2 (BRN2), N-MYC, enhancer of zeste homolog 2 (EZH2), and ataxia telangiectasia mutated (ATM) (Dardenne et al. 2016, Bishop et al. 2017, Ku et al. 2017, Mu et al. 2017, Yin et al. 2019). Alterations of these downstream mediators, like ATM upregulation, promote enzalutamide resistance in vitro, while genetic ablation or pharmacological inhibition of ATM in EnzR cells confers sensitivity (Yin et al. 2019). The clinical translation of these findings remains ongoing. (c) 2021 Society for Endocrinology Published by Bioscientifica Ltd. Printed in Great Britain 


\section{Alternative drivers in $\mathrm{BCa}$}

Loss of ER expression was initially thought to be the dominant mechanism of de novo resistance to tamoxifen (Ingle et al. 1991). This ER-negative phenotype may be related to either selection of ER-negative clones or epigenetic alterations. Epigenetic modifiers have been shown to reactivate ER- $\alpha$ expression in ER-negative BCa cells (Li et al. 2013c). In the absence of ER signaling, amplification of another driver, the human epidermal growth factor receptor 2 (HER2/Neu or ERBB2) is sufficient to confer tamoxifen resistance in vitro and in vivo (Benz et al. 1992, Kurokawa et al. 2000). Furthermore, EGFR/ HER2 kinase inhibitors have been shown to sensitize TamR-BCa cells (Kurokawa et al. 2000). Additional studies have shown the clinical relevance of this therapeutic strategy, where HER2 monoclonal antibody tratuzumab/ herceptin improves survival in primary and metastatic BCa patients, independent of HR status (Kaufman et al. 2009). In addition, enhanced mitogen-activated protein kinase (MAPK) signaling is noted in $~ 15 \%$ of TamR-BCa (Razavi et al. 2018). Alterations in the MAPK pathway (including GOF HER2 mutations, neurofibromin (NF1) loss, and epidermal growth factor receptor (EGFR) amplification) are mutually exclusive with ER mutations in patients, and promote fulvestrant resistance in vitro, indicating that MAPK activation may be an important factor in driving therapy resistance (Oh et al. 2001, Holloway et al. 2004, Razavi et al. 2018). In support of this, EGFR kinase and ERK/ MEK inhibitors confer sensitivity to fulvestrant in resistant BCa cells (Razavi et al. 2018). Clinical trials to assess the efficacy of EGFR and ERK/MEK inhibitors are ongoing.

Cyclin D1 and cyclin-dependent kinase 4/6 are important growth factor cell cycle regulatory components, and enhanced cyclin D1-CDK4/6 signaling is critical for growth factorindependent proliferation (Kato et al. 1993, Matsushime et al. 1994, Zwijsen et al. 1997). Cyclin D1 overexpression is associated with tamoxifen resistance and has been shown to independently activate ER-mediated transcription in the absence of estrogen in vitro (Zwijsen et al. 1997, Kenny et al. 1999). Strong preclinical data has demonstrated that CDK4/6 inhibitor, palbociclib, can overcome acquired tamoxifen resistance and synergize with antiestrogen therapy (Finn et al. 2009). Together, these findings have inspired several clinical trials revealing that palbociclib and other CDK 4/6 inhibitors, in combination with fulvestrant, increase PFS in patients with advanced, therapy resistant $\mathrm{ER}+\mathrm{BCa}$, when compared to endocrine therapy alone (Finn et al. 2009, Cristofanilli et al. 2016). Thus, there is considerable evidence that suggests cyclin D1/CDK 4/6 can act as a driver of tamoxifen resistance in vitro, as well as the clinic.

\section{Discussion}

Hormone-dependent cancers remain dependent on the NR that drives their primary malignancy, and maintaining NR signaling through NR overexpression, mutation or alternative splicing, increased hormone synthesis, or altering coregulator expression can drive endocrine therapy resistance. However, the frequency with which these alterations occur and drive therapy resistance in $\mathrm{BCa}$ and $\mathrm{PCa}$ are significantly different. For instance, $>50 \%$ of EnzR-CRPC patients have AR amplification, and $\mathrm{AR}$ overexpression is a proven mechanism of resistance in PCa; in contrast, $\sim 15 \%$ of TamR-BCa patients have increased ER expression, and it is unclear whether this enables tamoxifen resistance (Table 1). While increased NR expression enhances responsiveness to low agonist levels, the differences in frequency may be attributed to the relative potency, affinity, and clinical use of the antagonists (enzalutamide and tamoxifen). Tamoxifen has a higher affinity for ER than E2, while enzalutamide has a lower affinity for AR than DHT. The weaker selection pressure of enzalutamide may allow the CRPC cell to overexpress AR and maintain AR signaling. In support of this hypothesis, AR overexpression is much more common (75\%) after treatment with less avid antiandrogens, like bicalutamide (Koivisto \& Rantala 1999). We speculate that AR amplification may be a less common driver of therapy resistance with a more potent AR antagonist. In addition, enzalutamide is more commonly used at a later clinical stage (after primary hormonal therapy in CRPC rather than in primary $\mathrm{PCa}$ ) than tamoxifen, which is more commonly given as an adjuvant hormonal therapy to premenopausal, early stage ER+ BCa patients and less frequently to metastatic patients. A better comparison may be to evaluate ER amplification rates after tamoxifen treatment to postmenopausal women whom present with metastatic ER+ BCa. Together, we would expect that earlier use of a more potent AR antagonist or AR degrader may lead to less compensatory AR amplification as a molecular driver of resistance in PCa (Table 1).

The duration of ER-targeted therapies in BCa has been defined by level 1 clinical evidence from randomized clinical trials showing that ten years of tamoxifen treatment is associated with a significantly lower recurrence and mortality rate, compared to five years of treatment (Davies et al. 2013). The benefit of prolonging treatment is likely due to tamoxifen's cytostatic effect on dormant micrometastases. While clinical trials with neoadjuvant androgen deprivation therapy did not show a significant benefit in terms of disease recurrence or progression, 
earlier use of AR-targeted agents in non-metastatic PCa have shown clinical utility (Akitake et al. 2018, Hussain et al. 2018). From a molecular basis, the earlier and more prolonged use of AR-targeted agents in clinically localized PCa may target a limited spectrum of AR alterations more effectively and have the same effect as tamoxifen in BCa. The optimal timing and duration of AR-targeted therapies needs to be delineated from randomized clinical trials for patients with clinically localized PCa.

Interestingly, NR LBD mutations are a much more common mechanism of therapy resistance for ER (20-30\%) than AR (5-10\%) (Toy et al. 2013, Robinson et al. 2015, Conteduca et al. 2017, Razavi et al. 2018, Abida et al. 2019) (Table 1). These findings may be attributed to critical differences in the LBD, location of the LBD mutations, and the role of helix 12 in LBD function. Typically, AR LBD mutations occur within the ligand-binding pocket (LBP) of the LBD and alter the binding of the antagonist to the receptor. Individual AR LBD mutants may convert specific antagonists to agonists: AR LBD mutants that arise in response to one antiandrogen (e.g. F876L after enzalutamide) may still respond to a second antiandrogen (bicalutamide). Additionally, AR LBD mutations do not result in ligand-independent activity. In contrast, ER LBD mutations are outside the true LBP (on helix 12) and alter access to the LBD. These mutants have decreased affinity for both agonists and antagonists and have ligandindependent activity. Thus, ER LBD mutations offer a competitive growth advantage to TamR-BCa cells and may explain why ER LBD mutants are more commonly seen and more likely to drive therapy resistance than AR mutations (Table 1). We strongly believe that effective agents targeting ER LBD mutants in $\mathrm{BCa}$ represent a significant unmet need.

While AR splice variants have constitutive activity and are more commonly seen in PCa than ER splice variants in $\mathrm{BCa}$, their role as an independent driver of therapy resistance is still not clear. AR splice variants are primarily noted in the context of AR amplification and their ability to function independent of the full-length AR is still controversial (Table 1). Agents that selectively target these variants will be critical for defining whether AR splice variants are proven drivers of antiandrogen resistance.

In both hormone-dependent cancers, alterations in coregulators and transcriptional machinery promote resistance by enhancing transcriptional activity of the cognate NR, and thus have relatively the same prevalence in endocrine therapy-resistant patients. The same is true for increased hormone synthesis, which can enable intratumoral agonists to outcompete antagonists and continue to drive pro-proliferative programs in both $\mathrm{PCa}$ and $\mathrm{BCa}$ (Table 1). We propose that functional redundancy of coregulators may lead to significant heterogeneity in the coregulator profile and detract from the efficacy of agents targeting individual NR coregulators.

Because NRs have similar NR-DNA binding elements, ligand affinities, and transcriptional programs, NR crosstalk and substitution can effectively enable therapy resistance in both hormone-dependent cancers. Although alternative NRs are commonly seen in therapy-resistant patients and mechanistically shown to drive resistance, therapeutic strategies targeting these alternative NRs are currently being investigated and have not been proven in the clinic (Table 1 ). We postulate that effective biomarkers may be needed to identify which tumors are driven by alternative NRs, and thus define responsiveness to NR-targeting drugs.

The vast majority of therapy-resistant tumors maintain NR signaling; however, a significant proportion of advanced cancers lose NR signaling and subsequently switch to alternative drivers. Although this is seen in both $\mathrm{PCa}$ and $\mathrm{BCa}$, it is a more prevalent mechanism of therapy resistance in BCa. Approximately 10-15\% of EnzR-PCa will lose AR, while 15-30\% of TamR-BCa lose ER and switch to an alternative driver (Table 1 ). The reason behind this differential frequency is unclear; however, it may be related to the TP53/RB1 status, where TP53 may act as the primary gate-keeper. Under selective pressure, it is possible that when TP53 is lost by deletion or LOF mutation, it could allow for the acquisition of numerous mutations and aberrant genomic events, including RB1 loss and subsequent NR independence. Approximately $20-30 \%$ of BCa have RB1 loss, and RB1 loss is enriched following endocrine therapy in conjunction with ER loss (Pharoah et al. 1999, Robinson et al. 2017). Loss of RB1 occurs in $~ 10-15 \%$ of mCRPC (in conjunction with TP53) and tends to be concurrent with AR loss (Abida et al. 2019). Due to the accumulation of mutations potentially contributed by TP53/RB1 loss, these endocrine therapyresistant tumors are primarily reliant on alternative molecular drivers. Importantly, significant heterogeneity in the alternative molecular drivers is likely, and further molecular characterization of these tumors will be needed to identify possible therapeutic targets and agents.

Our comparative overview of two hormonedependent cancers - $\mathrm{BCa}$ and $\mathrm{PCa}$ - indicates that these cancers have a significant addiction to their primary NR driver and will take extraordinary steps to maintain that oncogenic addiction. While more potent therapies https://erc.bioscientifica com https://doi.org/10.1530/ERC-20-0272 (c) 2021 Society for Endocrinology Published by Bioscientifica Ltd. Printed in Great Britain 
targeting/degrading these NRs are in development, their clinical utility must be balanced with both their adverse side effects and their likelihood of selectively targeting a more aggressive, therapy-resistant cancer. The optimal timing and duration of each NR-targeted therapy must be defined. Strategies to target alternative non-NR molecular drivers in these cancers should be explored. With the widespread adoption of somatic sequencing, alternative therapeutic agents, such as poly (ADP-ribose) polymerase (PARP) inhibitors for tumors with DNA damage defects should be evaluated in the upfront setting.

\section{Conclusion}

Elucidating the molecular drivers of antiandrogen and antiestrogen resistance has enhanced our understanding of factors that drive endocrine therapy resistance and disease progression. Interestingly, while similar mechanisms are employed in maintaining the addiction of the cancer cell to the primary NR oncogenic driver, their relative contributions to therapy resistance in $\mathrm{BCa}$ and $\mathrm{PCa}$ are clearly distinct, likely due to differences in the clinical stage, relative affinity and binding of these antagonists to the NR, and intrinsic differences between AR and ER. These data indicate that distinct therapeutic strategies are needed to overcome endocrine therapy resistance in $\mathrm{BCa}$ and PCa to prolong patient survival.

\section{Declaration of interest}

$\mathrm{G} \vee \mathrm{R}$ is a named inventor in a patent for ERX-11.

\section{Funding}

This work was funded by grants from the National Institutes of Health (1F31CA243276-01A1) and Cancer Prevention and Research Institute of Texas (RP160157) to E B B, the Department of Defense (W81XWH-19-1-0363, W81XWH-17-1-0674), the Wilson Foundation, National Institutes of Health (1R01CA200787, 5R01CA223828), Prostate Cancer Foundation Challenge Award, Mimi and John Cole Foundation, and Charles Y. Pak grant to G V R.

\section{References}

Abida W, Cyrta J, Heller G, Prandi D, Armenia J, Coleman I, Cieslik M, Benelli M, Robinson D, Van Allen EM, et al. 2019. Genomic correlates of clinical outcome in advanced prostate cancer. PNAS 116 11428-11436. (https://doi.org/10.1073/pnas.1902651116)

Agoulnik IU, Vaid A, Nakka M, Alvarado M, Bingman 3rd WE, Erdem H, Frolov A, Smith CL, Ayala GE, Ittmann MM, et al. 2006 Androgens modulate expression of transcription intermediary factor 2, an androgen receptor coactivator whose expression level correlates with early biochemical recurrence in prostate cancer. Cancer Research $6 \mathbf{6}$ 10594-10602. (https://doi.org/10.1158/0008-5472.CAN-06-1023)

Akitake N, Shiota M, Obata H, Takeuchi A, Kashiwagi E, Imada K, Kiyoshima K, Inokuchi J, Tatsugami K \& Eto M 2018 Neoadjuvant androgen-deprivation therapy with radical prostatectomy for prostate cancer in association with age and serum testosterone. Prostate International 6 104-109. (https://doi.org/10.1016/j. prnil.2017.10.002)

Aleskandarany MA, Abduljabbar R, Ashankyty I, Elmouna A, Jerjees D, Ali S, Buluwela L, Diez-Rodriguez M, Caldas C, Green AR, et al. 2016 Prognostic significance of androgen receptor expression in invasive breast cancer: transcriptomic and protein expression analysis. Breast Cancer Research and Treatment 159 215-227. (https://doi.org/10.1007/ s10549-016-3934-5)

Antonarakis ES, Lu C, Wang H, Luber B, Nakazawa M, Roeser JC, Chen Y, Mohammad TA, Chen Y, Fedor HL, et al. 2014 AR-V7 and resistance to enzalutamide and abiraterone in prostate cancer. New England Journal of Medicine 371 1028-1038. (https://doi.org/10.1056/ NEJMoa1315815)

Anzick SL, Kononen J, Walker RL, Azorsa DO, Tanner MM, Guan XY, Sauter G, Kallioniemi OP, Trent JM \& Meltzer PS 1997 AIB1, a steroid receptor coactivator amplified in breast and ovarian cancer. Science 277 965-968. (https://doi.org/10.1126/science.277.5328.965)

Arora VK, Schenkein E, Murali R, Subudhi SK, Wongvipat J, Balbas MD, Shah N, Cai L, Efstathiou E, Logothetis C, et al. 2013 Glucocorticoid receptor confers resistance to antiandrogens by bypassing androgen receptor blockade. Cell 155 1309-1322. (https://doi.org/10.1016/j. cell.2013.11.012)

Azad AA, Volik SV, Wyatt AW, Haegert A, Le Bihan S, Bell RH, Anderson SA, Mcconeghy B, Shukin R, Bazov J, et al. 2015 Androgen receptor gene aberrations in circulating cell-free DNA: biomarkers of therapeutic resistance in castration-resistant prostate cancer. Clinical Cancer Research 21 2315-2324. (https://doi.org/10.1158/1078-0432. CCR-14-2666)

Balbas MD, Evans MJ, Hosfield DJ, Wongvipat J, Arora VK, Watson PA, Chen Y, Greene GL, Shen Y \& Sawyers CL 2013 Overcoming mutation-based resistance to antiandrogens with rational drug design. eLife 2 e00499. (https://doi.org/10.7554/eLife.00499)

Baniahmad A, Leng X, Burris TP, Tsai SY, Tsai MJ \& O'Malley BW 1995 The tau 4 activation domain of the thyroid hormone receptor is required for release of a putative corepressor(s) necessary for transcriptional silencing. Molecular and Cellular Biology 15 76-86. (https://doi.org/10.1128/mcb.15.1.76)

Bardou VJ, Arpino G, Elledge RM, Osborne CK \& Clark GM 2003 Progesterone receptor status significantly improves outcome prediction over estrogen receptor status alone for adjuvant endocrine therapy in two large breast cancer databases. Journal of Clinical Oncology 21 1973-1979. (https://doi.org/10.1200/JCO.2003.09.099)

Basudan A, Priedigkeit N, Hartmaier RJ Sokol ES Bahreini A, Watters RJ, Boisen MM, Bhargava R, Weiss KR, Karsten MM, et al. 2019. Frequent ESR1 and CDK pathway copy-number alterations in metastatic breast cancer. Molecular Cancer Research 17 457-468. (https://doi.org/10.1158/1541-7786.MCR-18-0946)

Beije N, Sieuwerts AM, Kraan J, Van NM, Onstenk W, Vitale SR, Van Der Vlugt-Daane M, Dirix LY, Brouwer A, Hamberg P, et al. 2018 Estrogen receptor mutations and splice variants determined in liquid biopsies from metastatic breast cancer patients. Molecular Oncology 12 48-57. (https://doi.org/10.1002/1878-0261.12147)

Benz CC, Scott GK, Sarup JC, Johnson RM, Tripathy D, Coronado E, Shepard HM \& Osborne CK 1992 Estrogen-dependent, tamoxifenresistant tumorigenic growth of MCF-7 cells transfected with HER2/ neu. Breast Cancer Research and Treatment 24 85-95. (https://doi. org/10.1007/BF01961241)

Bishop JL, Thaper D, Vahid S, Davies A, Ketola K, Kuruma H, Jama R, Nip KM, Angeles A, Johnson F, et al. 2017 The master neural transcription factor BRN2 is an androgen receptor-suppressed driver https://erc bioscientifica com

https://doi.org/10.1530/ERC-20-0272 c) 2021 Society for Endocrinology Published by Bioscientifica Ltd. Printed in Great Britain 
of neuroendocrine differentiation in prostate cancer. Cancer Discovery 7 54-71. (https://doi.org/10.1158/2159-8290.CD-15-1263)

Brodie AM 1985 Aromatase inhibition and its pharmacologic implications. Biochemical Pharmacology 34 3213-3219. (https://doi. org/10.1016/0006-2952(85)90337-5)

Brown MS \& Goldstein JL 1980 Multivalent feedback regulation of HMG CoA reductase, a control mechanism coordinating isoprenoid synthesis and cell growth. Journal of Lipid Research 21 505-517.

Brzozowski AM, Pike AC, Dauter Z, Hubbard RE, Bonn T, Engström O, Ohman L, Greene GL, Gustafsson JA \& Carlquist M 1997 Molecular basis of agonism and antagonism in the oestrogen receptor. Nature 389 753-758. (https://doi.org/10.1038/39645)

Cai C, Chen S, Ng P, Bubley GJ, Nelson PS, Mostaghel EA, Marck B, Matsumoto AM, Simon NI, Wang H, et al. 2011 Intratumoral de novo steroid synthesis activates androgen receptor in castrationresistant prostate cancer and is upregulated by treatment with CYP17A1 inhibitors. Cancer Research 71 6503-6513. (https://doi. org/10.1158/0008-5472.CAN-11-0532)

Cao L, Xiang G, Liu F, Xu C, Liu J, Meng Q, Lyu S, Wang S \& Niu Y 2019 A high AR:ER $\alpha$ or PDEF:ER $\alpha$ ratio predicts a sub-optimal response to tamoxifen therapy in ER $\alpha$-positive breast cancer. Cancer Chemotherapy and Pharmacology 84 609-620. (https://doi. org/10.1007/s00280-019-03891-6)

Catalano S, Giordano C, Panza S, Chemi F, Bonofiglio D, Lanzino M, Rizza P, Romeo F, Fuqua SA, Maggiolini M, et al. 2014 Tamoxifen through GPER upregulates aromatase expression: a novel mechanism sustaining tamoxifen-resistant breast cancer cell growth. Breast Cancer Research and Treatment 146 273-285. (https://doi.org/10.1007/ s10549-014-3017-4)

Cavaillès V, Dauvois S, L'Horset F, Lopez G, Hoare S, Kushner PJ \& Parker MG 1995 Nuclear factor RIP140 modulates transcriptional activation by the estrogen receptor. EMBO Journal 14 3741-3751. (https://doi.org/10.1002/j.1460-2075.1995.tb00044.x)

Chen JD \& Evans RM 1995 A transcriptional co-repressor that interacts with nuclear hormone receptors. Nature 377 454-457. (https://doi. org/10.1038/377454a0)

Chen CD, Welsbie DS, Tran C, Baek SH, Chen R, Vessella R, Rosenfeld MG \& Sawyers CL 2004 Molecular determinants of resistance to antiandrogen therapy. Nature Medicine 10 33-39. (https://doi.org/10.1038/nm972)

Conteduca V, Wetterskog D, Sharabiani MTA, Grande E, FernandezPerez MP, Jayaram A, Salvi S, Castellano D, Romanel A, Lolli C, et al. 2017 Androgen receptor gene status in plasma DNA associates with worse outcome on enzalutamide or abiraterone for castration-resistant prostate cancer: a multi-institution correlative biomarker study. Annals of Oncology 28 1508-1516. (https://doi.org/10.1093/annonc/mdx155)

Creevey L, Bleach R, Madden SF, Toomey S, Bane FT, Varešlija D, Hill AD, Young LS \& Mcilroy M 2019 Altered steroid milieu in AI-resistant breast cancer facilitates AR mediated gene-expression associated with poor response to therapy. Molecular Cancer Therapeutics 18 1731-1743. (https://doi.org/10.1158/1535-7163.MCT-18-0791)

Cristofanilli M, Turner NC, Bondarenko I, Ro J, Im SA, Masuda N, Colleoni M, Demichele A, Loi S, Verma S, et al. 2016 Fulvestrant plus palbociclib versus fulvestrant plus placebo for treatment of hormone-receptor-positive, HER2-negative metastatic breast cancer that progressed on previous endocrine therapy (PALOMA-3): final analysis of the multicentre, double-blind, phase 3 randomised controlled trial. Lancet: Oncology 17 425-439. (https://doi. org/10.1016/S1470-2045(15)00613-0)

D'Amato NC, Gordon MA, Babbs B, Spoelstra NS, Carson Butterfield KT, Torkko KC, Phan VT, Barton VN, Rogers TJ, Sartorius CA, et al. 2016 Cooperative dynamics of AR and ER activity in breast cancer Molecular Cancer Research 14 1054-1067. (https://doi. org/10.1158/1541-7786.MCR-16-0167)

Daniel AR, Gaviglio AL, Knutson TP, Ostrander JH, D'Assoro AB, Ravindranathan P, Peng Y, Raj GV, Yee D \& Lange CA 2015
Progesterone receptor-B enhances estrogen responsiveness of breast cancer cells via scaffolding PELP1- and estrogen receptor-containing transcription complexes. Oncogene 34 506-515. (https://doi. org/10.1038/onc.2013.579)

Dardenne E, Beltran H, Benelli M, Gayvert K, Berger A, Puca L, Cyrta J, Sboner A, Noorzad Z, Macdonald T, et al. 2016 N-Myc induces an EZH2-mediated transcriptional program driving neuroendocrine prostate cancer. Cancer Cell 30 563-577. (https://doi.org/10.1016/j. ccell.2016.09.005)

Davies C, Pan H, Godwin J, Gray R, Arriagada R, Raina V, Abraham M, Medeiros Alencar VH, Badran A, Bonfill X, et al. 2013 Long-term effects of continuing adjuvant tamoxifen to 10 years versus stopping at 5 years after diagnosis of oestrogen receptor-positive breast cancer: Atlas, a randomised trial. Lancet 381 805-816. (https://doi. org/10.1016/S0140-6736(12)61963-1)

Debes JD, Sebo TJ, Lohse CM, Murphy LM, Haugen DA \& Tindall DJ 2003 p300 in prostate cancer proliferation and progression. Cancer Research 63 7638-7640.

Dehm SM, Schmidt LJ, Heemers HV, Vessella RL \& Tindall DJ 2008 Splicing of a novel androgen receptor exon generates a constitutively active androgen receptor that mediates prostate cancer therapy resistance. Cancer Research 68 5469-5477. (https://doi. org/10.1158/0008-5472.CAN-08-0594)

Delozier T, Spielmann M Macé-Lesec'H J, Janvier M, Hill C, Asselain B, Julien JP, Weber B, Mauriac L, Petit JC, et al. 2000. Tamoxifen adjuvant treatment duration in early breast cancer: initial results of a randomized study comparing short-term treatment with long-term treatment. Fédération Nationale des Centres de Lutte Contre le Cancer Breast Group. Journal of Clinical Oncology 18 3507-3512. (https://doi.org/10.1200/JCO.2000.18.20.3507)

Dombernowsky P, Smith I, Falkson G, Leonard R, Panasci L, Bellmunt J, Bezwoda W, Gardin G, Gudgeon A, Morgan M, et al. 1998 Letrozole, a new oral aromatase inhibitor for advanced breast cancer: double-blind randomized trial showing a dose effect and improved efficacy and tolerability compared with megestrol acetate. Journal of Clinical Oncology 16 453-461. (https://doi.org/10.1200/ JCO.1998.16.2.453)

Dowsett M \& Haynes BP 2003 Hormonal effects of aromatase inhibitors: focus on premenopausal effects and interaction with tamoxifen. Journal of Steroid Biochemistry and Molecular Biology 86 255-263. (https://doi.org/10.1016/s0960-0760(03)00365-0)

Encarnación CA, Ciocca DR, Mcguire WL, Clark GM, Fuqua SA \& Osborne CK 1993 Measurement of steroid hormone receptors in breast cancer patients on tamoxifen. Breast Cancer Research and Treatment 26 237-246. (https://doi.org/10.1007/BF00665801)

Fabian C, Tilzer L \& Sternson L 1981 Comparative binding affinities of tamoxifen, 4-hydroxytamoxifen, and desmethyltamoxifen for estrogen receptors isolated from human breast carcinoma: correlation with blood levels in patients with metastatic breast cancer. Biopharmaceutics and Drug Disposition 2 381-390. (https://doi. org/10.1002/bdd.2510020407)

Fankhauser M, Tan Y, Macintyre G, Haviv I, Hong MK, Nguyen A, Pedersen JS, Costello AJ, Hovens CM \& Corcoran NM 2014 Canonical androstenedione reduction is the predominant source of signaling androgens in hormone-refractory prostate cancer. Clinical Cancer Research 20 5547-5557. (https://doi.org/10.1158/1078-0432. CCR-13-3483)

Fanning SW, Jeselsohn R, Dharmarajan V, Mayne CG, Karimi M, Buchwalter G, Houtman R, Toy W, Fowler CE, Han R, et al. 2018 The SERM/SERD Bazedoxifene disrupts ESR1 helix 12 to overcome acquired hormone resistance in breast cancer cells. eLife $\mathbf{7}$ e37161. (https://doi.org/10.7554/eLife.37161)

Feng S, Tang Q, Sun M, Chun JY, Evans CP \& Gao AC 2009 Interleukin-6 increases prostate cancer cells resistance to bicalutamide via TIF2. Molecular Cancer Therapeutics 8 665-671. (https://doi.org/10.1158/1535-7163.MCT-08-0823) (c) 2021 Society for Endocrinology Published by Bioscientifica Ltd. Printed in Great Britain 
Finn RS, Dering J, Conklin D, Kalous O, Cohen DJ, Desai AJ, Ginther C, Atefi M, Chen I, Fowst C, et al. 2009 PD 0332991, a selective cyclin D kinase $4 / 6$ inhibitor, preferentially inhibits proliferation of luminal estrogen receptor-positive human breast cancer cell lines in vitro. Breast Cancer Research 11 R77. (https://doi.org/10.1186/bcr2419)

Fu X, Jeselsohn R, Pereira R, Hollingsworth EF, Creighton CJ, Li F, Shea M, Nardone A, De Angelis C, Heiser LM, et al. 2016 FOXA1 overexpression mediates endocrine resistance by altering the ER transcriptome and IL-8 expression in ER-positive breast cancer. PNAS 113 E6600-E6609. (https://doi.org/10.1073/pnas.1612835113)

Girault I, Lerebours F, Amarir S, Tozlu S, Tubiana-Hulin M, Lidereau R \& Bièche I 2003 Expression analysis of estrogen receptor alpha coregulators in breast carcinoma: evidence that NCOR1 expression is predictive of the response to tamoxifen. Clinical Cancer Research $\mathbf{9}$ 1259-1266.

Grasso CS, Wu YM, Robinson DR, Cao X, Dhanasekaran SM, Khan AP, Quist MJ, Jing X, Lonigro RJ, Brenner JC, et al. 2012 The mutational landscape of lethal castration-resistant prostate cancer. Nature $\mathbf{4 8 7}$ 239-243. (https://doi.org/10.1038/nature11125)

Guo Z, Yang X, Sun F, Jiang R, Linn DE, Chen H, Chen H, Kong X, Melamed J, Tepper CG, et al. 2009 A novel androgen receptor splice variant is up-regulated during prostate cancer progression and promotes androgen depletion-resistant growth. Cancer Research 69 2305-2313. (https://doi.org/10.1158/0008-5472.CAN-08-3795)

Halachmi S, Marden E, Martin G, Mackay H, Abbondanza C \& Brown M 1994 Estrogen receptor-associated proteins: possible mediators of hormone-induced transcription. Science 264 1455-1458. (https://doi. org/10.1126/science.8197458)

Hara T, Miyazaki J, Araki H, Yamaoka M, Kanzaki N, Kusaka M \& Miyamoto M 2003 Novel mutations of androgen receptor: a possible mechanism of bicalutamide withdrawal syndrome. Cancer Research 63 149-153.

Hartmaier RJ, Trabucco SE, Priedigkeit N, Chung JH, Parachoniak CA, Vanden Borre P, Morley S, Rosenzweig M, Gay LM,

Goldberg ME, et al. 2018 Recurrent hyperactive ESR1 fusion proteins in endocrine therapy-resistant breast cancer. Annals of Oncology 29 872-880. (https://doi.org/10.1093/annonc/mdy025)

Holloway JN, Murthy S \& El-Ashry D 2004 A cytoplasmic substrate of mitogen-activated protein kinase is responsible for estrogen receptoralpha down-regulation in breast cancer cells: the role of nuclear factor-kappaB. Molecular Endocrinology 18 1396-1410. (https://doi. org/10.1210/me.2004-0048)

Holst F, Stahl PR, Ruiz C, Hellwinkel O, Jehan Z, Wendland M, Lebeau A, Terracciano L, Al-Kuraya K, Jänicke F, et al. 2007 Estrogen receptor alpha (ESR1) gene amplification is frequent in breast cancer. Nature Genetics 39 655-660. (https://doi.org/10.1038/ng2006)

Holzbeierlein J, Lal P, Latulippe E, Smith A, Satagopan J, Zhang L, Ryan C, Smith S, Scher H, Scardino P, et al. 2004 Gene expression analysis of human prostate carcinoma during hormonal therapy identifies androgen-responsive genes and mechanisms of therapy resistance. American Journal of Pathology 164 217-227. (https://doi. org/10.1016/S0002-9440(10)63112-4)

Hörnberg E, Ylitalo EB, Crnalic S, Antti H, Stattin P, Widmark A, Bergh A \& Wikström P 2011 Expression of androgen receptor splice variants in prostate cancer bone metastases is associated with castrationresistance and short survival. PLOS ONE 6 e19059. (https://doi. org/10.1371/journal.pone.0019059)

Hu XQ, Chen WL, Ma HG \& Jiang K 2017 Androgen receptor expression identifies patient with favorable outcome in operable triple negative breast cancer. Oncotarget 8 56364-56374. (https://doi.org/10.18632/ oncotarget.16913)

Hussain M, Fizazi K, Saad F, Rathenborg P, Shore N, Ferreira U, Ivashchenko P, Demirhan E, Modelska K, Phung D, et al. 2018 Enzalutamide in men with nonmetastatic, castration-resistant prostate cancer. New England Journal of Medicine 378 2465-2474. (https://doi.org/10.1056/NEJMoa1800536)
Hwang JH, Seo JH, Beshiri ML, Wankowicz S, Liu D, Cheung A, Li J, Qiu X, Hong AL, Botta G, et al. 2019 CREB5 promotes resistance to androgen-receptor antagonists and androgen deprivation in prostate cancer. Cell Reports 29 2355-2370.e6. (https://doi.org/10.1016/j. celrep.2019.10.068)

Ingle JN, Twito DI, Schaid DJ, Cullinan SA, Krook JE, Mailliard JA, Tschetter LK, Long HJ, Gerstner JG \& Windschitl HE 1991 Combination hormonal therapy with tamoxifen plus fluoxymesterone versus tamoxifen alone in postmenopausal women with metastatic breast cancer. An updated analysis. Cancer $\mathbf{6 7}$ 886-891. (https://doi.org/10.1002/10970142(19910215)67:4<886::aid-cncr2820670405>3.0.co;2-o)

Jin HJ, Zhao JC, Wu L, Kim J \& Yu J 2014 Cooperativity and equilibrium with FOXA1 define the androgen receptor transcriptional program. Nature Communications 5 3972. (https://doi.org/10.1038/ ncomms4972)

Johnston SR, Saccani-Jotti G, Smith IE, Salter J, Newby J, Coppen M, Ebbs SR \& Dowsett M 1995 Changes in estrogen receptor, progesterone receptor, and pS2 expression in tamoxifen-resistant human breast cancer. Cancer Research 55 3331-3338.

Joseph JD, Lu N, Qian J, Sensintaffar J, Shao G, Brigham D, Moon M, Maneval EC, Chen I, Darimont B, et al. 2013 A clinically relevant androgen receptor mutation confers resistance to second-generation antiandrogens enzalutamide and ARN-509. Cancer Discovery 3 1020-1029. (https://doi.org/10.1158/2159-8290.CD-13-0226)

Kato J, Matsushime H, Hiebert SW, Ewen ME \& Sherr CJ 1993 Direct binding of cyclin $\mathrm{D}$ to the retinoblastoma gene product $(\mathrm{pRb})$ and $\mathrm{pRb}$ phosphorylation by the cyclin D-dependent kinase CDK4. Genes and Development 7 331-342. (https://doi.org/10.1101/gad.7.3.331)

Katzenellenbogen BS, Norman MJ, Eckert RL, Peltz SW \& Mangel WF 1984 Bioactivities, estrogen receptor interactions, and plasminogen activator-inducing activities of tamoxifen and hydroxy-tamoxifen isomers in MCF-7 human breast cancer cells. Cancer Research $\mathbf{4 4}$ $112-119$.

Kaufman B, Mackey JR, Clemens MR, Bapsy PP, Vaid A, Wardley A, Tjulandin S, Jahn M, Lehle M, Feyereislova A, et al. 2009 Trastuzumab plus anastrozole versus anastrozole alone for the treatment of postmenopausal women with human epidermal growth factor receptor 2-positive, hormone receptor-positive metastatic breast cancer: results from the randomized phase III TAnDEM study. Journal of Clinical Oncology 27 5529-5537. (https://doi.org/10.1200/ JCO.2008.20.6847)

Kawata H, Ishikura N, Watanabe M, Nishimoto A, Tsunenari T \& Aoki Y 2010 Prolonged treatment with bicalutamide induces androgen receptor overexpression and androgen hypersensitivity. Prostate $\mathbf{7 0}$ 745-754. (https://doi.org/10.1002/pros.21107)

Kenny FS, Hui R, Musgrove EA, Gee JM, Blamey RW, Nicholson RI, Sutherland RL \& Robertson JF 1999 Overexpression of cyclin D1 messenger RNA predicts for poor prognosis in estrogen receptorpositive breast cancer. Clinical Cancer Research 5 2069-2076.

Kohli M, Ho Y, Hillman DW, Van Etten JL, Henzler C, Yang R, Sperger JM, Li Y, Tseng E, Hon T, et al. 2017 Androgen receptor variant AR-V9 is coexpressed with AR-V7 in prostate cancer metastases and predicts abiraterone resistance. Clinical Cancer Research 23 4704-4715. (https:// doi.org/10.1158/1078-0432.CCR-17-0017)

Koivisto PA \& Rantala I 1999 Amplification of the androgen receptor gene is associated with P53 mutation in hormone-refractory recurrent prostate cancer. Journal of Pathology 187 237-241. (https:// doi.org/10.1002/(SICI)1096-9896(199901)187:2<237::AIDPATH224>3.0.CO;2-I)

Komura K, Fujiwara Y, Uchimoto T, Saito K, Tanda N, Matsunaga T, Ichihashi A, Tsutsumi T, Tsujino T, Yoshikawa Y, et al. 2019 Comparison of radiographic progression-free survival and PSA response on sequential treatment using abiraterone and enzalutamide for newly diagnosed castration-resistant prostate cancer: a propensity score matched analysis from multicenter cohort. 
Journal of Clinical Medicine 8 1251. (https://doi.org/10.3390/ jcm8081251)

Kong Y, Cheng L, Mao F, Zhang Z, Zhang Y, Farah E, Bosler J, Bai Y, Ahmad N, Kuang S, et al. 2018 Inhibition of cholesterol biosynthesis overcomes enzalutamide resistance in castration-resistant prostate cancer (CRPC). Journal of Biological Chemistry 293 14328-14341. (https://doi.org/10.1074/jbc.RA118.004442)

Ku SY, Rosario S, Wang Y, Mu P, Seshadri M, Goodrich ZW, Goodrich MM, Labbé DP, Gomez EC, Wang J, et al. 2017 Rb1 and Trp53 cooperate to suppress prostate cancer lineage plasticity, metastasis, and antiandrogen resistance. Science 355 78-83. (https:// doi.org/10.1126/science.aah4199)

Kurokawa H, Lenferink AE, Simpson JF, Pisacane PI, Sliwkowski MX, Forbes JT \& Arteaga CL 2000 Inhibition of HER2/neu (erbB-2) and mitogen-activated protein kinases enhances tamoxifen action against HER2-overexpressing, tamoxifen-resistant breast cancer cells. Cancer Research 60 5887-5894.

Lavinsky RM, Jepsen K, Heinzel T, Torchia J, Mullen TM, Schiff R, DelRio AL, Ricote M, Ngo S, Gemsch J, et al. 1998 Diverse signaling pathways modulate nuclear receptor recruitment of N-CoR and SMRT complexes. PNAS 95 2920-2925. (https://doi.org/10.1073/ pnas.95.6.2920)

Lei JT, Shao J, Zhang J, Iglesia M, Chan DW, Cao J, Anurag M, Singh P, He X, Kosaka Y, et al. 2018 Functional annotation of ESR1 gene fusions in estrogen receptor-positive breast cancer. Cell Reports $\mathbf{2 4}$ 1434.e7-1444.e7. (https://doi.org/10.1016/j.celrep.2018.07.009)

Li S, Shen D, Shao J, Crowder R, Liu W, Prat A, He X, Liu S, Hoog J, Lu C, et al. 2013a Endocrine-therapy-resistant ESR1 variants revealed by genomic characterization of breast-cancer-derived xenografts. Cell Reports 4 1116-1130. (https://doi.org/10.1016/j.celrep.2013.08.022)

Li Y, Chan SC, Brand LJ, Hwang TH, Silverstein KA \& Dehm SM 2013b Androgen receptor splice variants mediate enzalutamide resistance in castration-resistant prostate cancer cell lines. Cancer Research $\mathbf{7 3}$ 483-489. (https://doi.org/10.1158/0008-5472.CAN-12-3630)

Li Y, Meeran SM, Patel SN, Chen H, Hardy TM \& Tollefsbol TO 2013c Epigenetic reactivation of estrogen receptor- $\alpha(E R \alpha)$ by genistein enhances hormonal therapy sensitivity in ERo-negative breast cancer. Molecular Cancer 12 9. (https://doi.org/10.1186/1476-4598-12-9)

Li Y, Yang R, Henzler CM, Ho Y, Passow C, Auch B, Carreira S, Nava Rodrigues D, Bertan C, Hwang TH, et al. 2020 Diverse AR gene rearrangements mediate resistance to androgen receptor inhibitors in metastatic prostate cancer. Clinical Cancer Research 26 1965-1976. (https://doi.org/10.1158/1078-0432.CCR-19-3023)

Liu C, Lou W, Zhu Y, Yang JC, Nadiminty N, Gaikwad NW, Evans CP \& Gao AC 2015 Intracrine androgens and AKR1C3 activation confer resistance to enzalutamide in prostate cancer. Cancer Research $\mathbf{7 5}$ 1413-1422. (https://doi.org/10.1158/0008-5472.CAN-14-3080)

Liu C, Yang JC, Armstrong CM, Lou W, Liu L, Qiu X, Zou B, Lombard AP, D'Abronzo LS, Evans CP, et al. 2019 AKR1C3 promotes AR-V7 protein stabilization and confers resistance to AR-targeted therapies in advanced prostate cancer. Molecular Cancer Therapeutics 18 1875-1886. (https://doi.org/10.1158/1535-7163.MCT-18-1322)

Locke JA, Guns ES, Lubik AA, Adomat HH, Hendy SC, Wood CA, Ettinger SL, Gleave ME \& Nelson CC 2008 Androgen levels increase by intratumoral de novo steroidogenesis during progression of castration-resistant prostate cancer. Cancer Research 68 6407-6415. (https://doi.org/10.1158/0008-5472.CAN-07-5997)

Lopez SM, Agoulnik AI, Zhang M, Peterson LE, Suarez E, Gandarillas GA, Frolov A, Li R, Rajapakshe K, Coarfa C, et al. 2016 Nuclear receptor corepressor 1 expression and output declines with prostate cancer progression. Clinical Cancer Research 22 3937-3949. (https://doi. org/10.1158/1078-0432.CCR-15-1983)

Lu R, Hu X, Zhou J, Sun J, Zhu AZ, Xu X, Zheng H, Gao X, Wang X, Jin H, et al. 2016 COPS5 amplification and overexpression confers tamoxifen-resistance in ER $\alpha$-positive breast cancer by degradation of NCoR. Nature Communications 7 12044. (https://doi.org/10.1038/ ncomms12044)
Luo J, Attard G, Balk SP, Bevan C, Burnstein K, Cato L, Cherkasov A, De Bono JS, Dong Y, Gao AC, et al. 2018 Role of androgen receptor variants in prostate cancer: report from the 2017 mission androgen receptor variants meeting. European Urology 73 715-723. (https://doi. org/10.1016/j.eururo.2017.11.038)

Matsushime H, Quelle DE, Shurtleff SA, Shibuya M, Sherr CJ \& Kato JY 1994 D-type cyclin-dependent kinase activity in mammalian cells. Molecular and Cellular Biology 14 2066-2076. (https://doi. org/10.1128/mcb.14.3.2066)

Mohammed H, Russell IA, Stark R, Rueda OM, Hickey TE, Tarulli GA, Serandour AA, Birrell SN, Bruna A, Saadi A, et al. 2015 Progesterone receptor modulates ER $\alpha$ action in breast cancer. Nature 523 313-317. (https://doi.org/10.1038/nature14583)

Mohler JL, Titus MA, Bai S, Kennerley BJ, Lih FB, Tomer KB \& Wilson EM 2011 Activation of the androgen receptor by intratumoral bioconversion of androstanediol to dihydrotestosterone in prostate cancer. Cancer Research 71 1486-1496. (https://doi. org/10.1158/0008-5472.CAN-10-1343)

Mostaghel EA, Marck BT, Plymate SR, Vessella RL, Balk S, Matsumoto AM, Nelson PS \& Montgomery RB 2011 Resistance to CYP17A1 inhibition with abiraterone in castration-resistant prostate cancer: induction of steroidogenesis and androgen receptor splice variants. Clinical Cancer Research 17 5913-5925. (https://doi. org/10.1158/1078-0432.CCR-11-0728)

Mu P, Zhang Z, Benelli M, Karthaus WR, Hoover E, Chen CC, Wongvipat J, Ku SY, Gao D, Cao Z, et al. 2017 SOX2 promotes lineage plasticity and antiandrogen resistance in TP53- and RB1-deficient prostate cancer. Science 355 84-88. (https://doi.org/10.1126/science.aah4307)

Nelson ER, Wardell SE, Jasper JS, Park S, Suchindran S, Howe MK, Carver NJ, Pillai RV, Sullivan PM, Sondhi V, et al. 2013 27-Hydroxycholesterol links hypercholesterolemia and breast cancer pathophysiology. Science $\mathbf{3 4 2}$ 1094-1098. (https://doi.org/10.1126/science.1241908)

Nettles KW, Gil G, Nowak J, Métivier R, Sharma VB \& Greene GL 2008 CBP is a dosage-dependent regulator of nuclear factor-kappaB suppression by the estrogen receptor. Molecular Endocrinology 22 263-272. (https://doi.org/10.1210/me.2007-0324)

Oh AS, Lorant LA, Holloway JN, Miller DL, Kern FG \& El-Ashry D 2001 Hyperactivation of MAPK induces loss of ERalpha expression in breast cancer cells. Molecular Endocrinology 15 1344-1359. (https:// doi.org/10.1210/mend.15.8.0678)

Oñate SA, Tsai SY, Tsai MJ \& O'Malley BW 1995 Sequence and characterization of a coactivator for the steroid hormone receptor superfamily. Science 270 1354-1357. (https://doi.org/10.1126/ science.270.5240.1354)

Pharoah PD, Day NE \& Caldas C 1999 Somatic mutations in the p53 gene and prognosis in breast cancer: a meta-analysis. British Journal of Cancer 80 1968-1973. (https://doi.org/10.1038/sj.bjc.6690628)

Ponnusamy S, Asemota S, Schwartzberg LS, Guestini F, Mcnamara KM, Pierobon M, Font-Tello A, Qiu X, Xie Y, Rao PK, et al. 2019 Androgen receptor is a non-canonical inhibitor of wild-type and mutant estrogen receptors in hormone receptor-positive breast cancers. iScience 21 341-358. (https://doi.org/10.1016/j.isci.2019.10.038)

Puhr M, Hoefer J, Eigentler A, Ploner C, Handle F, Schaefer G, Kroon J, Leo A, Heidegger I, Eder I, et al. 2018 The glucocorticoid receptor is a key player for prostate cancer cell survival and a target for improved antiandrogen therapy. Clinical Cancer Research 24 927-938. (https://doi.org/10.1158/1078-0432.CCR-17-0989)

Raj GV, Sareddy GR, Ma S, Lee TK, Viswanadhapalli S, Li R, Liu X, Murakami S, Chen CC, Lee WR et al. 2017 Estrogen receptor coregulator binding modulators (ERXs) effectively target estrogen receptor positive human breast cancers. eLife 6 e26857. (https://doi. org/10.7554/eLife.26857)

Ramanand SG, Chen Y, Yuan J, Daescu K, Lambros MB, Houlahan KE, Carreira S, Yuan W, Baek G, Sharp A, et al. 2020 The landscape of RNA polymerase II associated chromatin interactions in prostate cancer. Journal of Clinical Investigation 130 3987-4005. (https://doi. $\operatorname{org} / 10.1172 / \mathrm{JCI} 134260)$ 
Razavi P, Chang MT, Xu G, Bandlamudi C, Ross DS, Vasan N, Cai Y, Bielski CM, Donoghue MTA, Jonsson P, et al. 2018 The genomic landscape of endocrine-resistant advanced breast cancers. Cancer Cell 34 427.e6-438.e6. (https://doi.org/10.1016/j.ccell.2018.08.008)

Robinson D, Van Allen EM, Wu YM, Schultz N, Lonigro RJ, Mosquera JM, Montgomery B, Taplin ME, Pritchard CC, Attard G, et al. 2015 Integrative clinical genomics of advanced prostate cancer. Cell $\mathbf{1 6 1}$ 1215-1228. (https://doi.org/10.1016/j.cell.2015.05.001)

Robinson DR, Wu YM, Lonigro RJ, Vats P, Cobain E, Everett J, Cao X, Rabban E, Kumar-Sinha C, Raymond V, et al. 2017 Integrative clinical genomics of metastatic cancer. Nature 548 297-303. (https:// doi.org/10.1038/nature23306)

Roger P, Sahla ME, Mäkelä S, Gustafsson JA, Baldet P \& Rochefort H 2001 Decreased expression of estrogen receptor beta protein in proliferative preinvasive mammary tumors. Cancer Research 61 2537-2541.

Sharma NL, Massie CE, Ramos-Montoya A, Zecchini V, Scott HE, Lamb AD, Macarthur S, Stark R, Warren AY, Mills IG, et al. 2013 The androgen receptor induces a distinct transcriptional program in castration-resistant prostate cancer in man. Cancer Cell 23 35-47. (https://doi.org/10.1016/j.ccr.2012.11.010)

Shiau AK, Barstad D, Radek JT, Meyers MJ, Nettles KW, Katzenellenbogen BS, Katzenellenbogen JA, Agard DA \& Greene GL 2002 Structural characterization of a subtype-selective ligand reveals a novel mode of estrogen receptor antagonism. Nature Structural Biology 9 359-364. (https://doi.org/10.1038/nsb787)

Singhal H, Greene ME, Tarulli G, Zarnke AL, Bourgo RJ, Laine M, Chang YF, Ma S, Dembo AG, Raj GV et al. 2016 Genomic agonism and phenotypic antagonism between estrogen and progesterone receptors in breast cancer. Science Advances 2 e1501924. (https://doi. org/10.1126/sciadv.1501924)

Song X, Chen J, Zhao M, Zhang C, Yu Y, Lonard DM, Chow DC, Palzkill T, $\mathrm{Xu} \mathrm{J}, \mathrm{O}^{\prime}$ Malley BW, et al. 2016 Development of potent small-molecule inhibitors to drug the undruggable steroid receptor coactivator-3. PNAS 113 4970-4975. (https://doi.org/10.1073/pnas.1604274113)

Speirs V, Malone C, Walton DS, Kerin MJ \& Atkin SL 1999 Increased expression of estrogen receptor beta mRNA in tamoxifen-resistant breast cancer patients. Cancer Research 59 5421-5424.

Takeda DY, Spisák S, Seo JH, Bell C, O'Connor E, Korthauer K, Ribli D, Csabai I, Solymosi N, Szállási Z, et al. 2018 A somatically acquired enhancer of the androgen receptor is a noncoding driver in advanced prostate. Cancer Cell 174 422.e13-432.e13. (https://doi. org/10.1016/j.cell.2018.05.037)

Thewes V, Simon R, Schroeter P, Schlotter M, Anzeneder T, Büttner R, Benes V, Sauter G, Burwinkel B, Nicholson RI, et al. 2015 Reprogramming of the ERR $\alpha$ and $E R \alpha$ target gene landscape triggers tamoxifen resistance in breast cancer. Cancer Research 75 720-731. (https://doi.org/10.1158/0008-5472.CAN-14-0652)

Tomita S, Zhang Z, Nakano M, Ibusuki M, Kawazoe T, Yamamoto Y \& Iwase H 2009 Estrogen receptor alpha gene ESR1 amplification may predict endocrine therapy responsiveness in breast cancer patients. Cancer Science 100 1012-1017. (https://doi. org/10.1111/j.1349-7006.2009.01145.x)

Toy W, Shen Y, Won H, Green B, Sakr RA, Will M, Li Z, Gala K, Fanning S, King TA, et al. 2013 ESR1 ligand-binding domain mutations in hormone-resistant breast cancer. Nature Genetics $\mathbf{4 5}$ 1439-1445. (https://doi.org/10.1038/ng.2822)

Toy W, Weir H, Razavi P, Lawson M, Goeppert AU, Mazzola AM, Smith A, Wilson J, Morrow C, Wong WL, et al. 2017 Activating ESR1 mutations differentially affect the efficacy of ER antagonists. Cancer Discovery 7 277-287. (https://doi.org/10.1158/2159-8290.CD-15-1523)

Tran C, Ouk S, Clegg NJ, Chen Y, Watson PA, Arora V, Wongvipat J, Smith-Jones PM, Yoo D, Kwon A, et al. 2009 Development of a second-generation antiandrogen for treatment of advanced prostate cancer. Science 324 787-790. (https://doi.org/10.1126/ science.1168175)

Veldscholte J, Ris-Stalpers C, Kuiper GG, Jenster G, Berrevoets C, Claassen E, Van Rooij HC, Trapman J, Brinkmann AO \& Mulder E 1990 A mutation in the ligand binding domain of the androgen receptor of human $\mathrm{LNCaP}$ cells affects steroid binding characteristics and response to anti-androgens. Biochemical and Biophysical Research Communications 173 534-540. (https://doi.org/10.1016/s0006$291 x(05) 80067-1)$

Viswanathan SR, Ha G, Hoff AM, Wala JA, Carrot-Zhang J, Whelan CW, Haradhvala NJ, Freeman SS, Reed SC, Rhoades J, et al. 2018 Structural alterations driving castration-resistant prostate cancer revealed by linked-read genome sequencing. Cell 174 433.e19-447. e19. (https://doi.org/10.1016/j.cell.2018.05.036)

Viswanadhapalli S, Ma S, Sareddy GR, Lee TK, Li M, Gilbreath C, Liu X, Luo Y, Pratap UP, Zhou M et al. 2019 Estrogen receptor coregulator binding modulator (ERX-11) enhances the activity of CDK4/6 inhibitors against estrogen receptor-positive breast cancers. Breast Cancer Research 21 150. (https://doi.org/10.1186/ s13058-019-1227-8)

Wang Y, Lonard DM, Yu Y, Chow DC, Palzkill TG, Wang J, Qi R, Matzuk AJ, Song X, Madoux F, et al. 2014 Bufalin is a potent smallmolecule inhibitor of the steroid receptor coactivators SRC-3 and SRC-1. Cancer Research 74 1506-1517. (https://doi.org/10.1158/00085472.CAN-13-2939)

Watson PA, Chen YF, Balbas MD, Wongvipat J, Socci ND, Viale A, Kim K \& Sawyers CL 2010 Constitutively active androgen receptor splice variants expressed in castration-resistant prostate cancer require fulllength androgen receptor. PNAS 107 16759-16765. (https://doi. org/10.1073/pnas.1012443107)

Weiner M, Skoog L, Fornander T, Nordenskjöld B, Sgroi DC \& Stål O 2013 Oestrogen receptor co-activator AIB1 is a marker of tamoxifen benefit in postmenopausal breast cancer. Annals of Oncology 24 1994-1999. (https://doi.org/10.1093/annonc/mdt159)

Witzel I, Graeser M, Karn T, Schmidt M, Wirtz R, Schütze D, Rausch A, Jänicke F, Milde-Langosch K \& Müller V 2013 Androgen receptor expression is a predictive marker in chemotherapy-treated patients with endocrine receptor-positive primary breast cancers. Journal of Cancer Research and Clinical Oncology 139 809-816. (https://doi. org/10.1007/s00432-013-1382-8)

Yin Y, Xu L, Chang Y, Zeng T, Chen X, Wang A, Groth J, Foo WC, Liang C, Hu H, et al. 2019 N-Myc promotes therapeutic resistance development of neuroendocrine prostate cancer by differentially regulating miR-421/ATM pathway. Molecular Cancer 18 11. (https:// doi.org/10.1186/s12943-019-0941-2)

Zhang QX, Borg A, Wolf DM, Oesterreich S \& Fuqua SA 1997 An estrogen receptor mutant with strong hormone-independent activity from a metastatic breast cancer. Cancer Research 57 1244-1249.

Zhang Z, Zhou C, Li X, Barnes SD, Deng S, Hoover E, Chen CC, Lee YS, Zhang Y, Wang C, et al. 2020 Loss of CHD1 promotes heterogeneous mechanisms of resistance to AR-targeted therapy via chromatin dysregulation. Cancer Cell 37 584.e11-598.e11. (https://doi. org/10.1016/j.ccell.2020.03.001)

Zhou HJ, Yan J, Luo W, Ayala G, Lin SH, Erdem H, Ittmann M, Tsai SY \& Tsai MJ 2005 SRC-3 is required for prostate cancer cell proliferation and survival. Cancer Research 65 7976-7983. (https:// doi.org/10.1158/0008-5472.CAN-04-4076)

Zwijsen RM, Wientjens E, Klompmaker R, Van Der Sman J, Bernards R \& Michalides RJ 1997 CDK-independent activation of estrogen receptor by cyclin D1. Cell 88 405-415. (https://doi.org/10.1016/s00928674(00)81879-6)

Received in final form 6 October 2020

Accepted 23 November 2020

Accepted Manuscript published online 27 November 2020 https://erc bioscientifica com https://doi.org/10.1530/ERC-20-0272 (c) 2021 Society for Endocrinology Published by Bioscientifica Ltd. Printed in Great Britain 